\title{
Mälestused faasanikasvatusest Eestis, eriti Siniküla faasanifarmi loomisest ja likvideerimisest
}

Ülo Siimets

\begin{abstract}
Teesid: Artikkel annab ülevaate faasanikasvatuse ajaloost Eestis. Põhjalikumalt käsitletakse Eesti kõigi aegade suurima, Tartu Metsakombinaadi abimajandina tegutsenud Siniküla faasanifarmi loomist, tegevust ja likvideerimist. Kasutatud on isiklike mälestusi, ajalehtedes ja internetis leiduvat teavet faasanite kohta, küsitletud on endisi faasanifarmi töötajaid, jahimehi ja teisi faasanikasvatusega tegelevaid inimesi. Varaseimad faasanikasvatajad olid mõisad, kus neid linde kasvatati jahilinnuks. Siniküla farm rajati 1985. aastal alanud abimajandite rajamise käigus. 1987. aastaks oli seal 4700 lindu. Farmi kiirele likvideeriminele eelnesid muutused metsatööstusministeeriumi juhtkonnas ning Tartu Metsakombinaadi liitmine Tartu Mööblikombinaadiga ja metsatööstuskoondise Tarmeko sünd. Tarmeko juhtkond võttis faasanikasvatuse suhtes algusest peale eitava hoiaku. Faasanifarme on Eestisse rajatud ka hiljem ja neid tegutseb vähem või rohkem tulemuslikult tänapäevalgi. Uurimismaterjaliks on eelkõige mälestuslikud põimingud, mille abil on näidatud, et marginaalne ja eksootiline, samas ka atraktiivne linnukasvatusharu jätab põlvkondi kestvaid mälestusi ning paelub oma kaasaegsete, sh meedia tähelepanu.
\end{abstract}

Märksõnad: abimajandid, faasanid, faasanikasvatus, jahilinnukasvatus, jahindus, meediatekst, metsandus, plaanimajandus

Käesolevas artiklis püüan anda ülevaate faasanikasvatusest, eriti aga sellekohastest mälestustest ja pärimusest Eestis läbi aegade. Põhjalikumalt käsitlen omaaegse Eesti suurima faasanifarmi ehitamist ja sellega seotud probleeme ning püüan vastata küsimusele, miks farm likvideeriti. Kasutatud on isiklike mälestusi, ajalehtedes avaldatud ja internetis leiduvat faasanite kohta, küsitletud on endisi faasanifarmi töötajaid, jahimehi ja teisi faasanikasvatusega tegelevaid või asjatundlikke inimesi. Uurimismaterjaliks on eelkõige mälestuslikud põimingud, mille abil on näidatud, et marginaalne ja eksootiline, samas ka atraktiivne linnukasvatusharu jätab põlvkondi kestvaid mälestusi ning paelub oma kaasaegsete, sh meedia tähelepanu. Selle valdkonnaga seostuvad nn isikliku kogemuse lood põimuvad reaalsete faktidega ja loovad huvi- 
tava pärimuspildi. Artikli sihiks on anda ka detailne ülevaade nõukogude majandussüsteemi toimimisest ühe konkreetse näite varal. Seesugune abimajandi rajamine näitab aga ka suhteid ametliku ja mitteametliku majandustegevuse vahel, privilegeeritud sotsiaalse rühma (veteranid) mõju ja võimalusi omandisuhetes ning informaalsetes võrgustikes vastu võetud otsuseid ja hüvede ümberjagamisi (vt lähemalt Hann 1998).

\section{Faasanikasvatuse ajaloost}

Faasaneid on 48 liiki, kusjuures neist 47 on pärit Aasiast. Kauneimaks neist peetakse kuning-läikfaasanit. Maailmas kasvatatakse farmitingimustes mitmeid faasaniliike. Oma dekoratiivse välimuse tõttu on ta ka paljudes parkides ja kodudes dekoratiivlinnuks. Euroopas on faasanitest enimkasvatatavamad liigid kuningfaasan (Syrmaticus reevesi), jahifaasan (Phasianus colchicus), kuldfaasan (Chrysolophus pictus) ja teemantfaasan (Crysolophus amherstiae). Faasaneid kasvatatakse mõnedes maades (Prantsusmaa, Inglismaa, USA) ka lihalinnuna (faasanibroilerid).

Eesti farmides kasvatatakse põhiliselt jahifaasaneid. Üksikutel talude ja majapidamiste kodustes aedikutes on ka muid faasaneid, keda peetakse lemmiklindudena. Ometi oli praeguseks haruldaseks muutunud faasan 19. sajandi lõpus ja 20. sajandi algul üsna levinud jahilind paljudes Eesti metsades ja roostikes.

Näiteks praeguses Väike-Maarja vallas endises Äntu mõisas Rakvere-Vägeva maantee lähedal elasid faasanid Äntu järve ääres. Prillapatsi talul oli mõisnikuga kokkulepe talviseks faasanite lisatoitmiseks. Pärast Vabadussõda, kui mõisad natsionaliseeriti, lõppes ka lindude lisatoitmine. Faasanid elasid seal ilma lisatoitmiseta veel 1930. aastatel.

Ka Järvamaal Karinul ja Metsa mõisas elasid linnud looduses vabalt veel mitukümmend aastat pärast mõisa natsionaliseerimist. Seal olid lindudele tekkinud head talvitumistingimused viirpuutihnikutes. Viirpuupõõsastes oli raskendatud kiskjate ja muude metsloomade liikumine, seega oli lindudel kergem vaenlase eest põgeneda. Ka jäid viirpuudele talveks külge punased marjad, millest linnud toitusid ja ühtlasi levitasid viirpuuseemneid, suurendades nii endale sobilikku territooriumi. Kohalike jahimeeste mälestuse järgi lasti viimane faasan maha 1950. aastatel (Hinnosaar 2000-2001).

Endine Eesti Rahva Muuseumi direktor, praegu pensionil olev Aleksei Peterson vahendas oma isalt kuuldut, et Sangaste krahv Bergil olid Harimäe ümbruses asuvas Mäeküla metsas olnud 20. sajandi algul faasanid. Kohalikud talunikud olid vaatamata keelule ja metsavahtide kontrollile käi- 
nud linde püüdmas. Nende kättesaamine oli olnud suhteliselt kerge. Krahv olnud küll linnuküttide peale pahane, aga otseselt kedagi süüdistada ka ei saanud.

Postipaadi Helge kapteni Ivar Piirisaare andmetel elasid faasanid kunagi ka Prangli saarel, kuid rebased panid nad nahka (Podekrat 2005). Teated faasanite kasvatamise kohta on ka Taagepera mõisast: sinna olla linnud toodud enne Esimest maailmasõda. Hiljem nad hävisid (Kaldma 2005). Edukalt peeti faasaneid poolmetsiku jahilinnuna veel Saaremaal, Vigalas ja Väänas (Gladkov \& Dementjev \& Mihhejev \& Inozemtsev 1980: 172).

Kaupo Ilmet, Eesti Metsaseltsi juhataja, töötas 1959. aastal Aakre metskonna metsaülemana. Tema juhtimisel rajati Aakresse aedikud, kus oli võimalik vaadata põtru, metskitsi, metssigu ja ka faasaneid. Metskonna võrguga kaetud aedikus oli tookord umbes 100 lindu. Kui K. Ilmet viidi üle teisele töökohale, jätkas faasanikasvatust uus metsaülem Tõnis Hainsoo.

\section{Siniküla faasanifarm}

Kõigi aegade uurimaks faasanifarmiks Eestis oli Tartu Metsakombinaadi Siniküla faasanifarm. 1987. aasta sügisel oli seal umbes 4500 lindu, sh tõukarjas 2000 faasanit.

Järgnevalt edastan mälestusi sellest faasanifarmist.

1984. aastal algas Nõukogude Liidus suur abimajandite loomiste periood. NLKP Keskkomitee võttis vastu otsuse, et iga tööstusettevõte peab tootma sõltuvalt töötajate arvust teatud koguse liha. Eesti oli tol ajal lihatootmises ühe elaniku kohta Nõukogude Liidus esikohal. Siin toodeti liiaga kana-, looma- ja sealiha. Vaatamata sellele olid poed aeg-ajalt lihast ja vorstist tühjad, sest toodang eksporditi suurele kodumaale. Vabalt oli saada ainult subprodukte. Rahva hulgas liikus anekdoot, et Eestis kasvavad haruldased sead: neil on ainult pead, jalad ja sabad, rindkere aga puudub. Ka Eesti vorsti oli võimalik tihti saada Moskva toidukauplusest ja harvem Eesti omast. Eriti puudutas see korralikku suitsuvorsti.

Töötasin sel ajal Tartu Metsakombinaadi peainsenerina, seega ühtlasi direktori esimese asetäitjana. Mulle anti korraldus hakata tegelema loodava abimajandiga. Metsakombinaadi direktoril Rein Kippastol oligi selline komme, et kui mingi asi vajas kiiret lahendamist, torgati mind nagu punni augu ette. Siis oli teada, et asi saab lahendatud. Või oli see mõeldud minu kiusamiseks? Tõttöelda pidanuks abimajandiga tegelema ju hoopis majandusala asedirektor Meelis Ilus. Igatahes anti see ülesanne tookord mulle ja et käsk on täitmiseks, siis allusin sellele. 
Mõtlesin, et sigade ja lehmadega ei taha küll tegelema hakata. Mida siis toota? Varem metsameistrina töötades olin ma raielankide valikul külastanud mitmeid metskondi, kohanud vanu metsavahte ja metsaülemaid, kes rääkisid, et mõisavalitseja oli andnud nende vanematele või vanavanematele kätte faasanimunad ja käskinud need hauduva kana alla panna, et kana faasanitibud välja hauks. Kirjandusest leidsin, et jahifaasaneid kasvatati Eestis poolmetsiku jahilinnuna juba 19. sajandi teisest poolest, seda eriti edukalt Saaremaal, Vigalas, Väänas (Gladkov \& Dementjev \& Mihhejev \& Inozemtsev 1980). Ajalehest olin lugenud ning seda rääkisid Soomes käinud Eesti jahimehed, et faasanid elavad Soomes vabalt looduses. Ka teistes Euroopa riikides olid suured faasanifarmid.

Eesti Põllumajandus Akadeemias (EPA), praeguse Eesti Maaülikooli eelkäijas, töötas sel ajal minu hea sõber Renaldo Mändmets, praegune rahandusministeeriumi asekantsler välissuhtluse alal. Tema korraldas aeg-ajalt oma korteris ilusaid õhtuid, kuhu oli kutsutud mitmeid tuntud inimesi. Ta on ka hea kokk ja pakkus alati maitsvat šašlõkki ning haruldasi veine. Hiljem pidas ta vägevaid sünnipäevi. Näiteks pani ta oma sünnipäevaürituseks kinni terve Waide motelli, kus sünnipäev kestis mitmesuguste ürituste, lõkke ja ilutulestikuga mitu päeva. Või korraldati sünnipäev Baeri maja aias põlevate küünalde ja teenindavate kelneritega. Omal ajal väga suursugune üritus.

Hariduselt oli Renaldo Mändmets zootehnik, samas Eesti noorim teaduste kandidaat. Väitekirja oli ta kirjutanud kanakasvatusest (ka faasanid kuuluvad kanaliste seltsi). Vestlesin temaga abimajandite teemal, sh faasanitest. Ta soovitas oma väga häid tuttavaid teadlasi Panevežises, kus kasvatati instituudi lähedal jahifaasaneid - me võivat sõita nende lindlatega tutvuma.

Ma ei hakanud pikalt mõtlema. Tartu Metsakombinaadil oli väikebuss Latvija, bussijuhiks noor mees Boriss Titov. Ta oli nõus Leetu sõitma ja juba mõne päeva pärast asusime teele. Oli novembrikuu ja ilm üsna külm. Isegi lumi oli maha sadanud. R. Mändmets kutsus meiega kaasa professor Harald Tiku, kes oli olnud tema kandidaaditöö teaduslik juhendaja. Kaasa võeti veel Afganistani veteran, EPA zootehnikateaduskonnast välja heidetud tudeng Heino Jürviste, Renaldo Mändmetsa naine Ave ja minu naine Tiina.

Heino Jürviste oli kaks aastat tagasi saabunud Afganistanist. Oma jutu järgi oli ta noorsõdur ja väljaõppel Turkmeenias, kusagil Afganistani piiri lähedal. Neid õpetati dessantväelasteks. Väljaõpe ei olnud veel lõppenud ning õppustel oli jõutud kõigest langevarju pakkimiseni ja teoreetiliste loenguteni, kuidas käituda langevarjuhüppe ajal, kui ühel öösel (see oli Afganistani sõja esimesel päeval) anti häire - nagu sõjaväes tihti. Poistele pisteti pihku Kalašnikovi automaadid ja lahingupadrunid ning käsutati nad täisrelvastuses 
lennukisse. Lennuk lendas läbi pimeda öö. Ühel hetkel anti käsk langevarjuga alla hüpata. Paljud ei julgenud. Neile anti siis jalaga vastu tagumikku ja lükati lihtsalt lennukiluugist alla. Nii olid sõdurpoisid langevarjuga Kabuli lennuvälja kohal lennukist välja visatud. Neid võttis vastu maruline tulistamine. Enamik poisse, Heino Jürviste arvates $80 \%$ allavisatutest, hukkus. Alla jõudnud, alustasid mehed vastutulistamist. Lahing kestis mitu tundi. Kohale jõudnud tankid ja autodel saabunud maavägi lõpetasid vastupanu.

Hiljem oli ta suutnud ennast majandusosakonda smugeldada ja töötas väeosa kokana. Kord, kui nad läksid kesklaost provianti tooma, sattusid nad varitsusele. Lahingus olid kõik üksteise järel surma saanud. Heino Jürviste peitis end veoauto alla ja tulistas Kalašnikovist vaenlast. Kui afgaanid nägid, et vastupanu ei lõpe, oli auto leegiheitjast põlema süüdatud. Ka H. Jürviste olevat leegiheitjaleegiga üle kõhu saanud. Siis jõudsid abiväed kohale ja afgaanid lasid jalga. Meie reisikaaslasel oli õnnestunud ka seekord ellu jääda. Ta oli küll mitu kuud hospidalis ravil ja siis demobiliseeriti.

Kas see lugu päris nii oli või mitte, aga suur põletusarm oli tal kõhu peal küll. Ta oli selles sõjas siiski ellu jäänud. Kuna ta oli mitmeid kordi surmasuus olnud ja lahingus haavata saanud, oli ta väga närviline. Kui ta kusagil istus, jälgis ta kogu aeg silmade vilades ümbruskonda. Esimesel kohtumisel EPA filmiklubis jättis ta lausa hullumeelse mulje. Teda kutsutigi Afgaaniks.

EPAst visati ta välja ühe kuulsaks räägitud seiga pärast professor Kalju Põldvere eksamil. Eksamipileti küsimustele oli ta enam-vähem normaalselt ära vastanud. Professor Põldvere oli palunud lisaülesandena joonistada lehma udara läbilõike. Jürviste oli joonistanud ümmarguse mahuti, kust jooksis välja neli toru. Professor oli naerma hakanud ja ütelnud: "Ime, et sa neile torudele veel keeratavaid kraane külge ei joonistanud. Paistab, et sa ei ole lehmaudara pilti eluski näinud. Nii küll eksamilt läbi ei saa. Võid lahkuda.” Heino Jürviste oli raevunult pastapliiatsi vastu lauda visanud ja see põrganud laua pealt professorile näkku. Rektorile oli ette kantud, et üliõpilane viskas professorile pliiatsi näkku. Sellist asja ei andestatud. Üliõpilane eksmatrikuleeriti ja professor oli hüvastijätuks ütelnud: "Seni kuni mina EPAs töötan, sul teed siia kooli tagasi ei ole.”

R. Mändmets oli sel ajal ka EPA komsomolikomitee sekretär ja Heino Jürviste oli aidanud tal korraldada mitmeid üritusi, näiteks üleliidulisi võistlustantsuturniire. Ta oli selleks sobiv inimene, sest oli ka ise enne sõjaväge võistlustantsuga tegelnud. Vanast ajast oli tal tantsijate ja treenerite ringkonnas palju tutvusi. Peale selle oli $\mathrm{H}$. Jürviste väga osav sponsoritelt igat sorti auhindu välja ajama. Neid jätkus tal auhindadeks, sõprade sünnipäevakinkideks ja muudeks üritusteks. Just suure organiseerimisvõime tõttu meeldis H. Jürviste Renaldo Mändmetsale. 
Pakkusin R. Mändmetsale faasanifarmi teadusliku juhendaja kohta. Tema arvas, et metsakombinaadil võib ka Heino Jürvistest kasu olla. Ma usaldasin teda ja kutsusin ka H. Jürviste kaasa. Hiljem selgus, et mõnes mõttes oli tal õigus, aga mitte täielikult.

Sõit Panevežisesse läks libedalt. Õhtuks olime kohal. Peatusime linnaga sama nime kandvas hotellis ja läksime hotelli restorani õhtust sööma. Õhtu vapustavaim hetk oli see, kui restorani bänd hakkas mängima tangot ning Heino Jürviste kutsus ühe kohaliku neiu tantsima ja see pahaaimamatult ka läks. H. Jürviste ja tundmatu neiu jäid selle tantsu ajal ainukeseks paaris tantsupõrandal. Vaest neiut väänati, keerati ja pöörati metsikult võistlustantsu stiilis. Rahvas jäi vaikseks ja isegi restorani köögi kokad ruttasid pliidi tagant etendust vaatama. Tantsu lõppedes aplodeeriti üksmeelselt ja tormiliselt. H. Jürviste saatis higist nõretava daami tagasi lauda. Ükski teine saalis olev naisterahvas ei tahtnud demonstratsioontantsuetendust kaasa teha. Isegi meie seltskonna naised keeldusid Heino Jürvistega tantsimast.

Järgmisel hommikul kutsus Renaldo Mändmets kohalikust loomakasvatusinstituudist kaasa oma sõbra ja me sõitsime paarikümne kilomeetri kaugusel asuvasse faasanikasvandusse. Seal saime teada, et jahifaasan elab sellistes kohtades, kus on tihe taimestik, mis annab lindudele varjupaika ja toitu. Linnud vajavad läheduses ka veekogu. Täiskasvanud faasanid on vähenõudlikud ja elavad kruusa, liiva ja varikatuse olemasolul kergesti üle külma lumerohke talve. Paks lumevaip mõjub neile hukatuslikult siis, kui varikatuseid ei ole ja nad ei saa kätte liiva ega toitu. Jahifaasani eelistatumad elupaigad on veekogude lähedal asuvad lammimetsad, võsastikud, kõrkjastikud ja roostikud. Mida tihedam põõsastik, seda parem. Inimesi lind ei karda. Vanade metsade raie ja nende asendumine võsaga mõjub selle liigi populatsiooni suurenemisele soodsalt.

Panevežise lähedal farmis peeti üht faasanikukke 7-10 emafaasani kohta. Sulupinda arvestasid leedulased 1-1,5 $\mathrm{m}^{2}$ ühe tõulinnu kohta, lisaks vajasid linnud 3-5 $\mathrm{m}^{2}$ solaariumipinda. Solaariumiks nimetatakse võrguga ümbritsetud ja pealt võrguga kaetud jalutusväljakuid. Faasanid hakkavad munema aprillis-mais. Farmis peetavad linnud munevad hästi - kuni kolm korda rohkem kui vabas looduses. Looduses elavatel lindudel on kurnas 7-12 muna, farmis peetavatel 25-40. Faasanitibude asustustiheduseks kahel esimesel elunädalal on 25 tibu ühel ruutmeetril, 3.-7. elunädalani 2-3 tibu ruutmeetril, edaspidi vajasid nad sama palju pinda kui täiskasvanud linnud. Inkubaatoris kestab haudeperiood 3-4 nädalat.

Lindudele anti Leedus sama segajõusööta mis kanadele. Täiskasvanud linnud söövad päevas 70-80 grammi jõusööta. Ka toodi faasanitele söögiks peakapsast, lutserni, nõgeseid ja sibulaid. Faasanitibudele anti esimesel neljal 


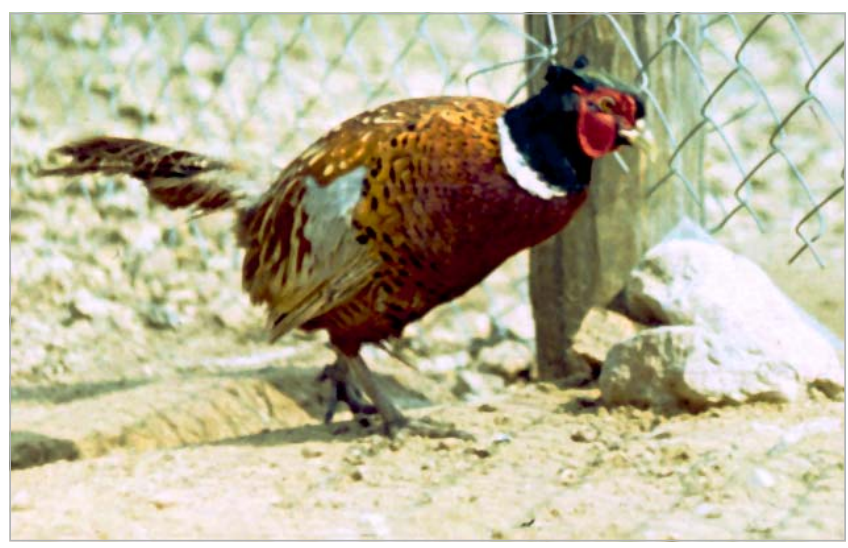

Foto 1. Faasanikukk.

Gunnar Zirnaski foto.

Foto 2. Jahifaasan (Phasianus colchicus). Foto internetist.
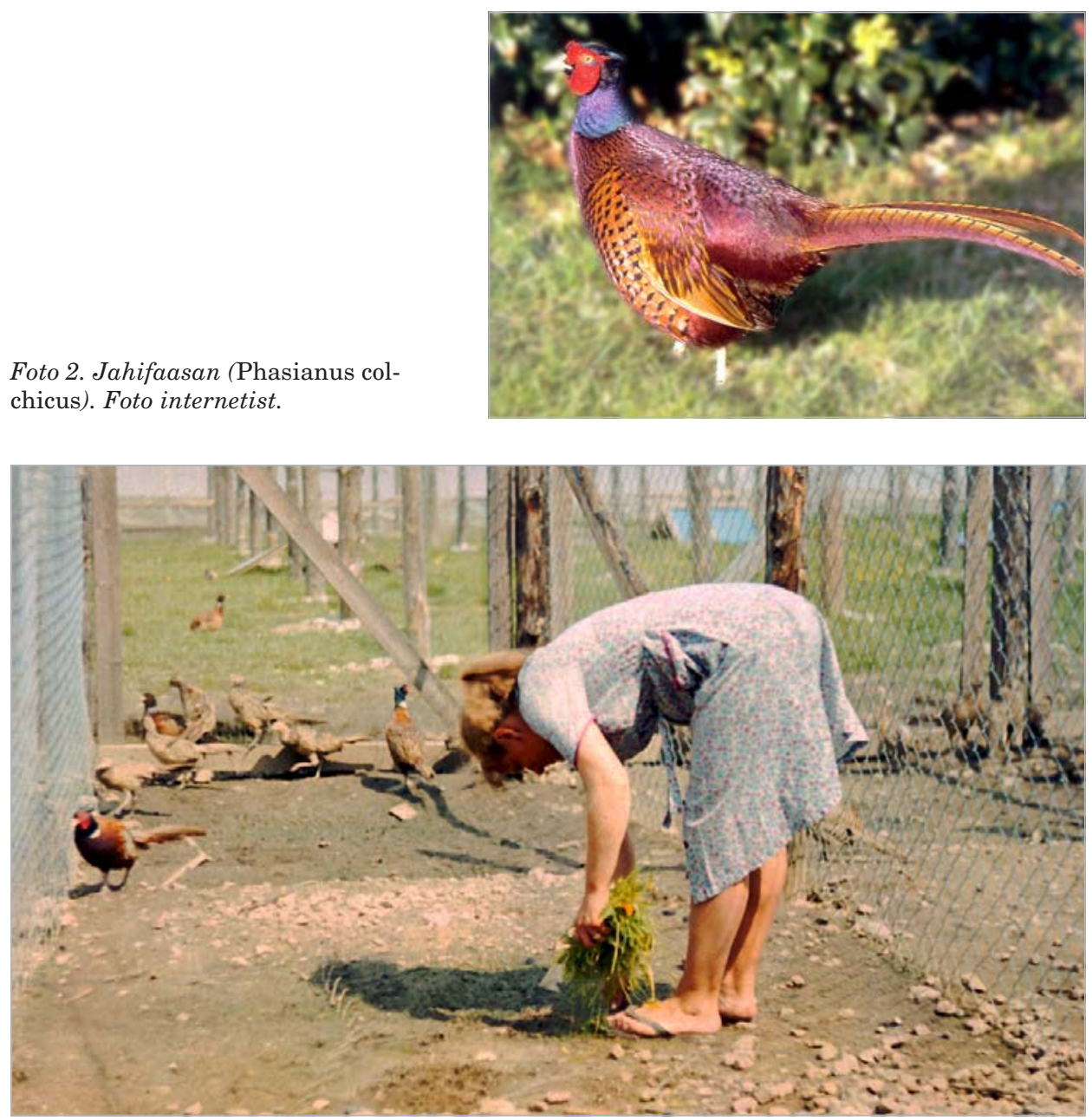

Foto 3. Faasanitalitaja Tiina Zirnask hoolealuseid toitmas. Gunnar Zirnaski foto. 


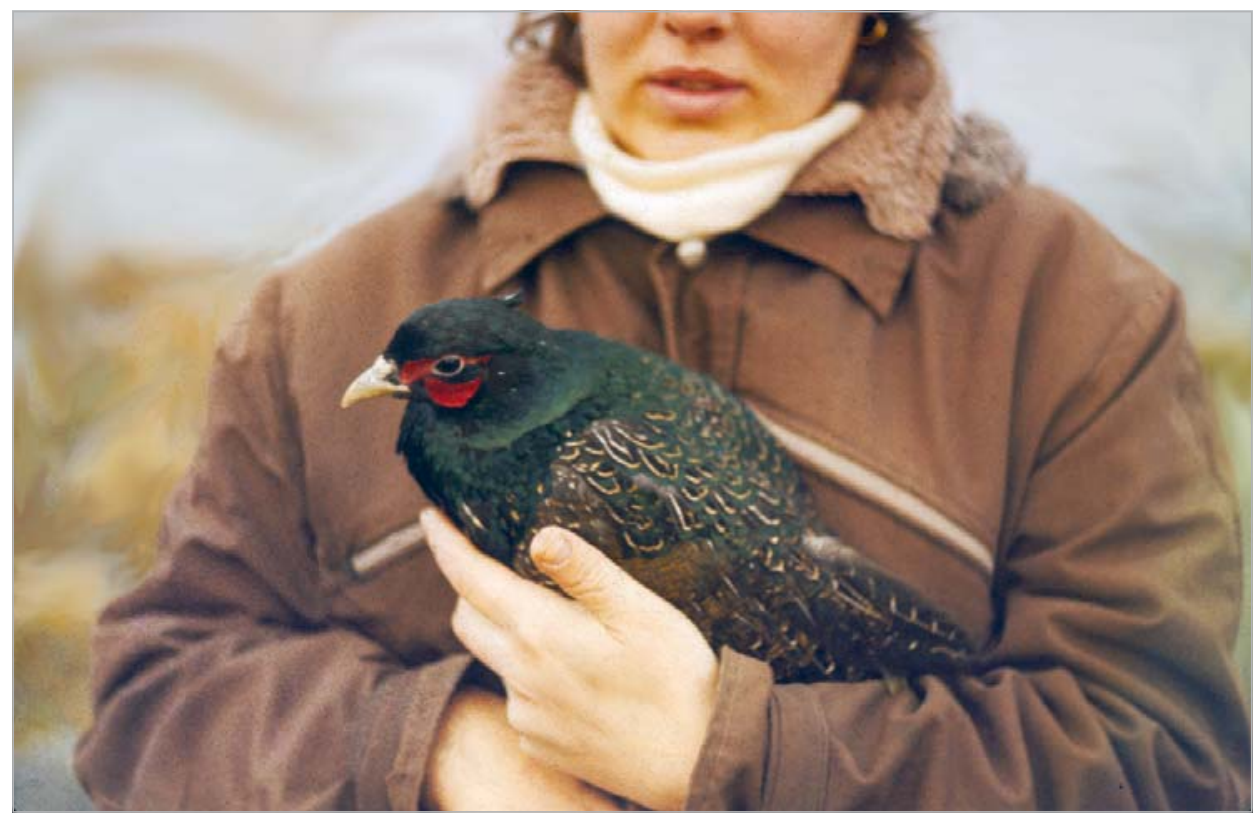

Foto 4. Kodunenud faasan. Gunnar Zirnaski foto.

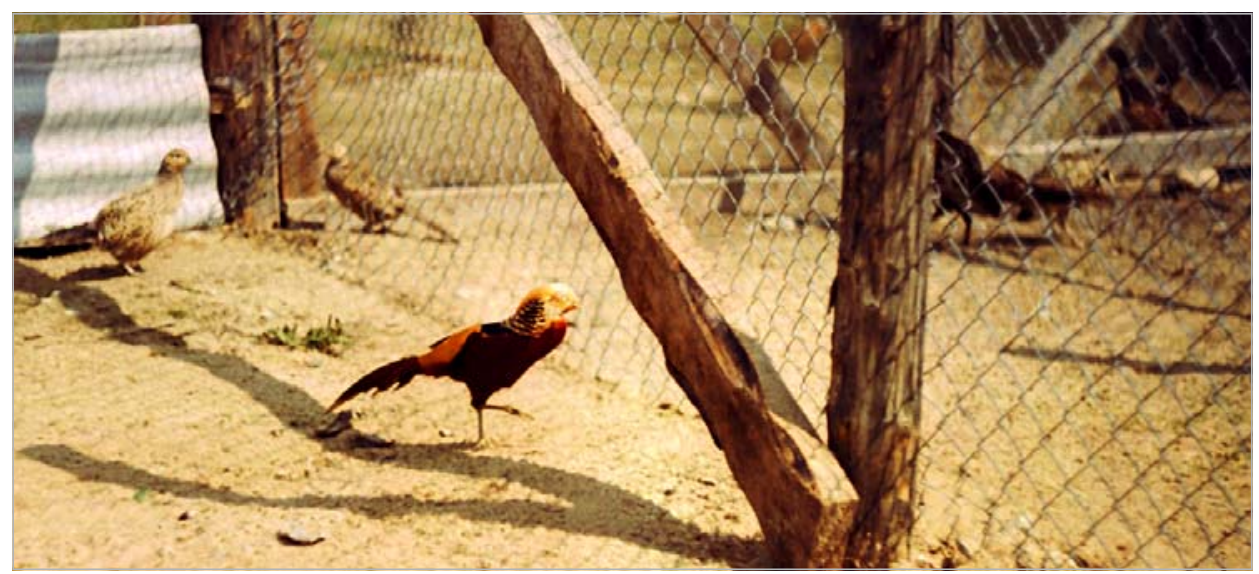

Foto 5. Kuldfaasan. Gunnar Zirnaski foto.

elunädalal kalkunitibudele ettenähtud jõusööta, millele lisati kõvaks keedetud ja peeneks hakitud kanamune ning hästi peeneks hakitud rohelist rohtu või peakapsast.

12-nädalased isafaasanid kaalusid 0,8-1 kg, emaslinnud olid paarsada grammi kergemad. Leedus kasvatati faasaneid eesmärgiga müüa need jahimajandusele sügisjahiks. Nõudlus oli suur. Kõik üleskasvatatud linnud osteti ära. 
Farmi jäi alles ainult tõukari. Jahihooajal tabatakse tavaliselt $30-40 \%$ ostetud ja loodusesse lahti lastud lindudest, ülejäänud jäävadki vabadusse. Et talved on Leedus lumevaesemad ja soojemad kui meil, elavad linnud ka talve üle ja paljunevad vabas looduses hästi.

Leedulased võtsid meid kenasti vastu. Pärast teabe jagamist katsid nad toreda laua ja pakkusid prooviks faasaniliha. Farmijuhataja lubas meile soovi korral müüa aprillis 300 täiskasvanud faasanit ja mais 1000 faasanitibu.

Arutasime tagasiteel Eestisse faasanikasvatuse probleeme. Professor Harald Tikk oli paar aastat tagasi juurutanud koos jahiarendaja Risto Vihaga Kaarepere metsakatsejaamas muskuspartide farmis pidamise. Ta arvas Leedus nähtu põhjal, et Leedus on asjal jumet, aga faasanikasvatus nõuab enne tulu saamist suuri kulutusi ja kahtles, et kas sellist raha on Eestis võimalik nii kiiresti saada. Oli ju vaja leida maa-ala, kuhu faasanifarm püstitada, teha projekt, see kinnitada ja farm üles ehitada. Aega oli selleks ainult pool aastat. Kusagilt oli vaja saada ka inkubaator, et munetud munadest tibud välja haududa. Harald Tikk arvas, et nii ruttu Nõukogude Liidus raha saada ei ole võimalik. Ka inkubaator tuli tellida mitu aastat ette ja selleks oli vaja spetsiaalset limiiti, mida tema meelest Tartu Metsakombinaadile küll keegi ei anna - isegi linnukasvatusfarmidel oli uusi inkubaatoreid raske saada. Sellepärast arvas ta, et õigem on faasanikasvatuse ideest loobuda ja võib-olla kunagi tulevikus uuesti proovida. Ka ei olnud tal oma sõnul sel hetkel aega asjaga tegelda.

Tagasitee algas hämaras. Ilm pimenes kiiresti. Paarkümmend kilomeetrit pärast Riiat nägime asfaltteel põtra, kes seisis Valga suunda näitava teeviida juures, nagu uuriks ta seda. Mäletan, et ütlesin bussijuhile, et näe, see põder soovib vist ka Eestisse minna. Järgmisel hetkel vilksatas midagi halli, buss pidurdas, käis hirmus mats, kostis klaasiklirin ning mulle lendas koos klaasikildudega näkku midagi tugevat ja teravat. Buss jäi seisma. Juht süütas salongivalgustuse. Tema nägu oli üleni verine ja kaetud tule käes sädelevate klaasikildudega. Leidsin istmete vahelt bussi salongipeegli, mis mulle vastu ninajuurt oli lennanud. Ninast jooksis verd ja nagu mulle teised ütlesid, ega mu nägu bussijuhi omast parem välja näinud, pigem oli ninast voolava vere tõttu isegi hullem.

Läksime autost välja. Panin lund näole. See muutus silmapilkselt punaseks. Samas oli nägu võimatu lumega nühkida, sest klaasikillud torkisid valusasti. Hoidsin seepärast lund seni ninal, kuni verejooks lõppes.

Vaatasime ringi. Selgus, et me olime sõitnud otsa teisele põdrale, kes ootamatult põõsastest bussi ette kargas. Nüüd lamas ta surnuna vereloigus bussi ees maas. Avariikoha lähedal oli mingi valvuriputka. Eakas valvuritädike tukkus õndsalt tugitoolis. Koputasime ukse kõrval asuvale aknale. Meie järsu ja 
ootamatu klaasile koputamise peale avas tädike silmad, kuid nähes läbi klaasi kahte verist nägu, hakkas ta kõigepealt karjuma. Püüdsime vene keeles selgitada, et tahame helistada. Lõpuks tädike rahunes ja avas ukse. Helistasin ja rääkisin juhtunust. Miilitsakorrapidaja käskis oodata. Külma oli umbes 20 kraadi. Õnneks lubas valvur oodata oma putkas. Ka teised tulid bussist valvuriruumi sooja. Seal oli seinal esmaabikapp. Kahjuks oli kapi sisu ammu ära kasutatud ja sealt ei olnud midagi võtta. Bussi esmaabikarp oli ka peaaegu tühi. Ave püüdis seal olnud vähese vatiga bussijuhi nägu tohterdada ja sealt suuremaid klaasikilde kätte saada. Tiina püüdis minu näoga teha sedasama. Kahjuks oli vatti väga vähe. Lisaks hakkas veri näos juba hüübima ja muutus tumedaks. Nii ei olnud väiksemaid kilde enam näha.

Miilits tuli poole tunni pärast. Vormistas juhtunu kohta kiiresti avariiprotokolli, käskis põdra miilitsavärvides auto peale tõsta, andis meile loa edasi sõita ja kadus sireeni huilates Riia suunas.

Jäime nõutult teele. Esiklaasi asemele polnud kusagilt kilet võtta. Tööpäev oli ammu lõppenud ja abi ei olnud loota kusagilt. Bussijuht arvas, et katsub kuidagi kodu poole logistada. Istusime bussi ja sõit läks lahti. Tuul ulus bussis ja oli hirmus külm. Korjasime kokku kõikide kottidest froteekäterätid ja riputasime need juhi selja taga oleva kardinatraadi külge. Naistel olid ka niit ja nõel kaasas. Suurte traagelduspistetega õmmeldi käterätid külgepidi kardinate külge. Nüüd tuul otse meile peale ei puhunud aga külm oli ikka. Korjasime endale peale kõik kotis olevad riideesemed. Osa riideid panime põlvedele ja ülejäänuga katsime ennast eest kinni. Bussijuht oli katastroofilises olukorras. Tema ei saanud endale midagi ette riputada. Ta sõitis bussiga umbes viiskümmend kilomeetrit, pidas siis kinni ja ütles, et ei suuda külma tõttu ennast liigutada ega julge edasi sõita - nii võib juhtuda avarii.

Mina ega ka keegi teine meie hulgast ei olnud kunagi bussi juhtinud ja me ei julgenud jäise tee peal harjutama hakata. Afgaan aga ütles, et teda on õpetatud sõitma kõigi masinatega, v.a helikopter. Loomulikult uskusime teda ja lubasime ta rooli taha. Bussijuht tuli juhiistmelt ära ja Heino Jürviste istus tema asemele. Ja olekski juhtunud esimene avarii. Enne veel, kui Boriss jõudis külguksest sisse, pani Jürviste käigu sisse ja andis gaasi. Buss liikus kohalt minema, Boriss rippus karjudes ukselingi küljes. Ka meie hakkasime karjuma. Kisa peale Afgaan pidurdas ja Borissil õnnestus bussi peale saada. Nii nad siis sõitsid kangelaslikult kordamööda bussi juhtides Tartuni. Sõitsime linna Riia maanteed pidi ja Puusepa tänavani jõudes otsustasime ka traumapunktist läbi minna. Oli öine aeg, kell võis olla pool kolm. Saime kiirabiuksest hoonesse sisse. Traumapunkt oli väga vaikne. Uksed olid suletud. Meie kolistamise peale tuli üks valges kitlis, unine ja alkoholi järel lõhnav umbes 50-aastane naisterahvas uksele. Kuulas meie jutu ära ja käratas: "Kaduge 
koju ja peske oma nägu kraani all puhtaks. Mina seda teie eest küll tegema ei hakka." Mis meil muud üle jäi. Boriss vedas meid kodudesse laiali ja pidimegi kraani all hakkama saama. Klaasikilde tuli veel mitu nädalat ühe või teise korba alt välja, aga õnneks kõik haavad paranesid korralikult ja arme suurt näkku ei jäänud.

Järgmisel nädalal sõitsime Põltsamaa lähedal asuvasse Sakala tõulinnukasvatussovhoosi. Seal kohtusime Renaldo Mändmetsa isa Ilmar Mändmetsaga, kes oli selle sovhoosi direktor. Rääkisin oma muredest seoses faasanikasvatusega ja küsisin tema arvamust. Põhimure oli, kuidas saada inkubaatorit. Ilmar Mändmets arvas, et võiks siiski proovida. Sakala allus otse üleliidulisele põllumajandusministeeriumile, seega Moskvale, ning selle finantseerimine ja varustamine igasuguse tehnika ja muu vajalikuga oli tunduvalt parem kui Eesti alluvusega ettevõtetel.

Ilmar Mändmets käis oma sovhoosi asjus Moskvas ja tagasi tulles teatas, et oli saanud järgmise aasta I kvartaliks inkubaatorieralduse. See oli küll ette nähtud kanamunade inkubeerimiseks, aga faasanid on ju kanalised. Seega oli vaja leida ainult nende munade inkubeerimise õige režiim suures inkubaatoris. Inkubaatori pidime kätte saama märtsis.

Kõik paistis klappivat. Kiiresti oli vaja hoonet, kuhu haudemasin panna, ja kerghooneid või angaare ning ehitusluba. Laeva lähedal Sinikülas asunud metsapunkt oli reorganiseerimise käigus likvideeritud. Seal oli olnud remonditöökoda, mille hoone jäi tühjaks, sest traktorite, autode ja muu tehnika korrastamine koondati Tartusse Võru tänav 77 selleks otstarbeks ehitatud uutesse töökodadesse. Seega oli võimalik Siniküla töökoda ja abiruumid abitootmishooneteks ümber ehitada.

Ruttasin oma murega Tartu rajooni peaarhitekti Aapo Neemre juurde. Võtsin asja selgitamiseks kaasa mõned konjakid ning koos A. Neemre ja arhitektidega lahendasimegi probleemi. Meie faasanifarmi projekteerimine võeti esmajärguliste tööde hulka. Saime suusõnalise loa alustada ehitustega enne projekti kinnitamist ja ametlikku ehitusluba.

Järgmistel päevadel leppisin direktor Rein Kippastoga kokku faasanifarmi asutamise ja inimeste tööle võtmise ning Leetu väljaõppele saatmise osas. Järgmisel nädalal võtsin Renaldo Mändmetsa tööle Tartu Metsakombinaadi faasanifarmi teaduslikuks konsultandiks ja Heino Jürviste faasanifarmi juhatajaks. Komandeerisin viimase väljaõppele Leedu faasanifarmi. Tartu Metsakombinaadi direktori asetäitja kapitaalehituse alal oli töölt lahkunud ja tema kohustused olid ajutiselt minu kanda. Nagu teada, on ajutine väga suhteline mõiste. Kuigi asedirektor oli töölt lahkunud paar aastat tagasi, ei leitud talle asetäitjat. Võib-olla oli küsimus ka selles, et ma sain suurepäraselt hakkama korraga kahe ametimehe tööga ja metsakombinaadi direktor ei kiirus- 


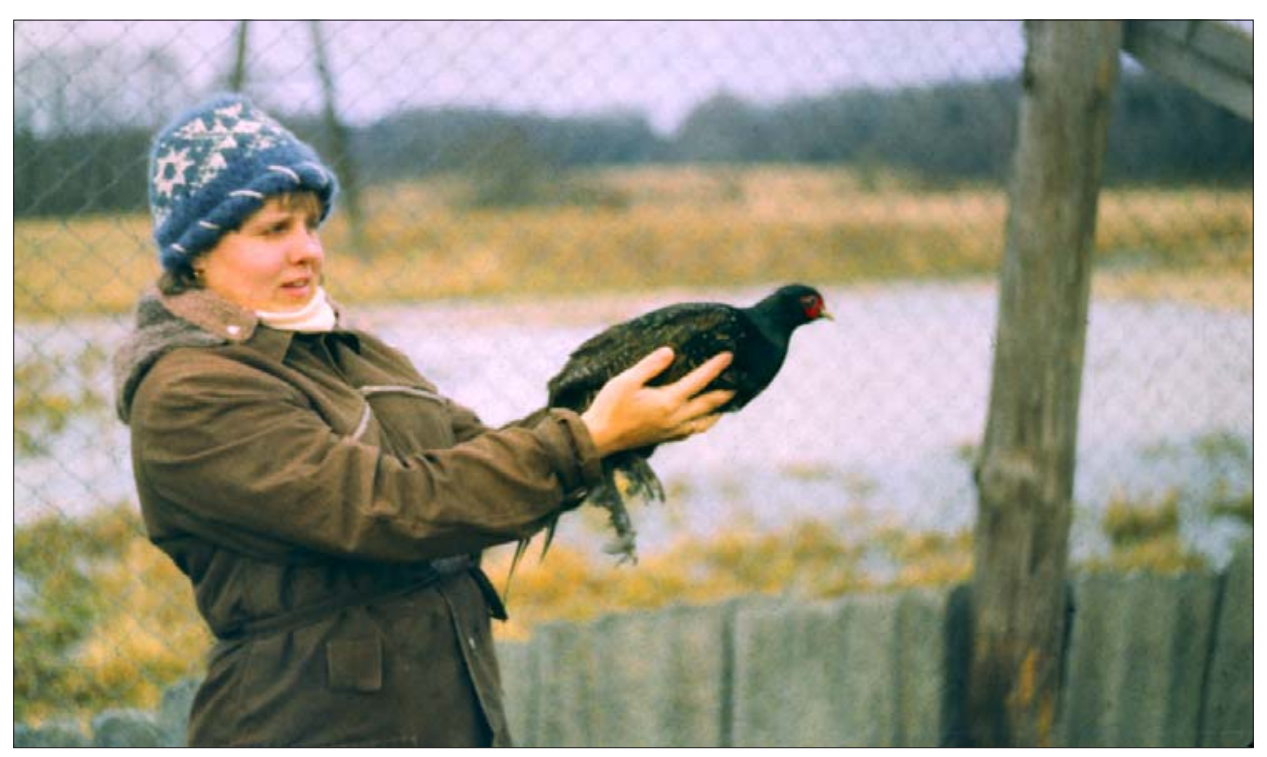

Foto 6. Faasanitalitaja Tiina Zirnask kodunenud faasaniga. Gunnar Zirnaski foto.

tanud uut meest otsima või ei pidanud vajalikuks sellele ametikohale kellegi leidmist. Oli kuidas oli, aga ka ehitusmehed olid kõik minu alluvuses. Lõpetasime enamiku töödest muudel ehitusobjektidel ja ma suunasin kõik ehitajad Sinikülla.

Ilmar Mändmetsa juhendamisel ehitasime töökoja ümber haudejaamaks. Kõrvaldati mittevajalikud ja ehitati juurde vajalikud vaheseinad. Hoone valmis tähtaegselt märtsi lõpuks. Siis tuli esimene tagasilöök. Meile lubatud ja Sakala Tõulinnukasvatusele Moskvas I kvartaliks eraldatud inkubaatorit tähtajaks kätte ei saanud. Tehas ei täitnud plaani ja inkubaatori valmimine nihkus II kvartalisse. Seega ei olnud meil mõtet sõita Leetu 300 täiskasvanud faasani järele, mis olid lubatud müüa Tartu Metsakombinaadile märtsi lõpul või aprilli algul. Põhjus oli lihtne: algas faasanite munemisaeg ja meil ei olnud ilma inkubaatorita faasanimunadega midagi peale hakata - need oleksid läinud lihtsalt mädanema.

Mis seal ikka, meil oli seega rohkem aega ettevalmistustöid teha. Ilmad läksid soojaks. Tartu rajooni arhitektuuribüroo väljastas faasanifarmi projekti ja tööjoonised. Renaldo Mändmets tundis EPAs agronoomiat õppivat Raul Mäesalu. Kohtusime temaga minu töökabinetis Tartus ja saime kokkuleppele, et ta organiseerib tudengitest nn musta maleva, mis hakkab ehitama Siniküla faasanifarmi.

Raul Mäesalu oli tudengimalevatest tuntud kui hea organisaator. Ta kogus kiiresti kokku rühma üliõpilasi, kes olid nõus kaasa lööma Siniküla faasani- 
farmi ehitusel. Rühma kuulusid Vahur Murutar, Kaupo Kiis, Aivar Salmu, Peeter Luige, Lagle ja Andres Saetalu, keegi Hillar, kelle perekonnanime ma ei mäleta, jne. Talvine tööjõud, Taga-Karpaatast pärit hutsuulid, olid sõitnud kodumaale ja nende ühiselamutubadesse majutasimegi faasanifarmi ehitajad. Algul hakkasid musta maleva poisid ehitama faasanite põhikarja hoonet, mis oli kavandatud tõufaasanite pidamiseks. Leedu eeskujul oli hoones planeeritud igale faasanile ruumi 1 ruutmeeter. Hoone oli jagatud $2 \times 7 \mathrm{~m}$ suurusteks eraldi ukse ja vaheseinaga lahtriks. Igasse sulgu oli kavas paigutada 7-15 faasanit. Hoone ees oli vaheseintega eraldatud ja võrguga kaetud solaarium. Leedu farmi eeskujul sai see ehitatud suurusega $2 \times 15 \mathrm{~m}$, seega tuli $3 \mathrm{~m}^{2}$ jalutusruumi ühe linnu kohta. Solaariumist edasi tuli plats, mis kaeti 120 meetri pikkuselt ja 100 laiuselt võrguga. Järgmisena ehitati tõukarja hoone suurune tugevdatud kilega kaetud hoone tibude kasvatamiseks.

Helistasin Saare ja Lääne kalurikolhoosi ja leppisin kokku kalavõrkude saamise kattevõrkudeks. Heino Jürviste käis nendel järel. Talle said kolhoosimehed tuttavaks ja hiljem käis ta veel mitu korda võrkude järel. Selgus, et osa võrke olid liiga suure silmaga. Faasanid lendavad püstloodis üles ja imelikul kombel venis võrk nii palju, et lind pääses vabadusse. Tavaliselt jalutasid vabakspääsenud faasanid farmi lähedal põllul. Seda kasutasid ära kanakullid. Faasanid ei osanud neid karta ja langesid röövlindude saagiks.

Olime sunnitud suurema auguga võrgud välja vahetama. Ka praegustes faasanifarmides on üheks probleemiks kanakullid. Näiteks Alaveskil elav ja faasaneid pidav Rein Kõiv kurdab, et faasanid, kes ei oska kulle karta, kohmitsevad võrkaia ääres ja langevad niimoodi röövlinnu küünte vahele (Kabun 2006). Ka Suure-Jaani valla Koidu talu faasanikasvatusega tegelev peremees Kalev Võitla kurtis telefonivestluses, et kanakullid ja kotkad teevad suurt kahju.

Saime kätte inkubaatori. Selle monteeris kokku ja häälestas Sakala tõulinnukasvatussovhoosi farmimehaanik Arne Lepperg. Faasanifarmi inkubaatori kõrval asuv ruum sai ehitatud ümber nn tibulaks. Tibulasse oli kavas paigutada koorunud tibud ja nad pidid seal elama 10 päeva. Sel ajal vajavad väiksed linnud erilist hoolitsust. Edasi tuli linnud viia suuremasse ruumi. Selleks ehitati faasanitibudele suurt kasvuhoonet meenutav kilehoone. Tibude soojendamiseks pandi üles võimsad, Sakala tõulinnukasvatussovhoosist saadud soojenduslambid. Juunikuuks olid hooned valmis ja lambid üleval. Kahjuks uskusin ma farmijuhataja juttu ega kontrollinud, kas kõik lambid on üles pandud.

Suur mure oli jõusöödaga. Faasanifarmi juhataja Heino Jürviste sõitis asjaajamiseks Tallinna põllumajandusministeeriumi. Seal tehti talle selgeks, et 
kõik tellimused oleksid pidanud olema esitatud kinnitamiseks ja jõusöödalimiidi saamiseks põllumajandusministeeriumile vähemalt aasta varem. Parem oleks muidugi olnud taotlused teha juba eelmisel viisaastakul. Tartu Metsakombinaadil ei olnud aga eelmisel viisaastakul veel mingit aimu faasanikasvatusest, rääkimata jõusöödast. Seega öeldi meile ära. Öeldi, et kui jõusööta oleks üle, võiksid linnukasvandused ise oma linnulihatoodangut suurendada.

Nüüd kulus ära Heino Jürviste Afganistani veterani pilet. Ta pani ennast kirja EKP Keskkomitee I sekretäri Karl Vaino jutule. Sõjaveterani piletil oli tõesti imepärane võim, mis avas kõik uksed. Teda võeti vastu praeguses välisministeeriumi hoones, kus nõukogude ajal asus Eestimaa Kommunistliku Partei Keskkomitee. Heino Jürviste oli töötanud Olümpia hotelli peakokana ja oskas hästi jutustada. Ta oli esimesele sekretärile mananud silme ette ridamisi imelisi toite, mida oleks võimalik valmistada ja hiljem ka tellida keskkomitee sööklasse ning mujalegi Eestisse. H. Jürviste ise ütles, et panin mehe suu linnuliha järel vett jooksma veel enne, kui linnud Eestisse olid jõudnud. Selle jutuajamise tulemusena hakkas faasanikasvatuse idee seltsimees Vainole meeldima ja tema juurde kutsuti asjaga tegelevad isikud. Ka seesama õnnetu tegelane põllumajandusministeeriumist oli kohal, kes oli pidanud Heino Jürvistele pika loengu aasta- ja viisaastakuplaanidest ning limiitidest. Nüüd heideti mehele ette piiratud silmaringi ja sõjaveteranide vajaduste eiramist. Oli kuidas oli, aga nädala pärast saabus Siniküla faasanifarmi õuele suur jõusöödaauto. Vooliku kaudu pumbati jõusööt salvedesse. Kombikormi vedaja oli küll imestunud, et kohapeal polnud jõusöödapunkrit, kuhu tavaliselt jõusööt pumbati, aga mis see tema asi oli. Tema pidi jõusööda kohale tooma. Meie ise olime rumalad, sest polnud varem linnukasvatusega tegelnud. See selgus hiljem.

Faasanifarmi ümbrusse siginesid rotid, kellel oli vaba voli süüa nii palju kui tahad, sigida lõpmatuseni ja isegi oma käikusid jõusööda sisse kaevata. Väljapandud mürki nad ei söönud või kui sõid, siis see ei mõjunud. Igatahes kubises faasanifarmi ümbrus aasta pärast rottidest. Sinikülla farmi vaatama käinud Tartu Metsakombinaadi tootmisdirektor Märt Saaroni sõnutsi ei olnud ta elus sees korraga nii palju ja nii julgeid rotte näinud. Sellepärast ma 2005. aastal eriti ei imestanudki, kui lugesin lehest, et Saru faasaniaiast leiti "rotikuningas" - sabasidpidi sõlme jäänud rotipundar -, sest kogemustest teadsin faasaniaias palju rotte olevat (vt Kononenko 2005). "Rotikuningaga" oli aga nii, et see leiti 16. jaanuaril 2005. Tegemist on üliharuldase nähtusega. Maailmas on leitud viimasel 400 aastal 58 rotikuningat. Maailma muuseumides oli varem juba kuus rotikuningat ja nüüd on see viimane "rotikuningas" vaadata Tartu Ülikooli zooloogiamuuseumis. Eestis on üldse leitud kolm "ro- 


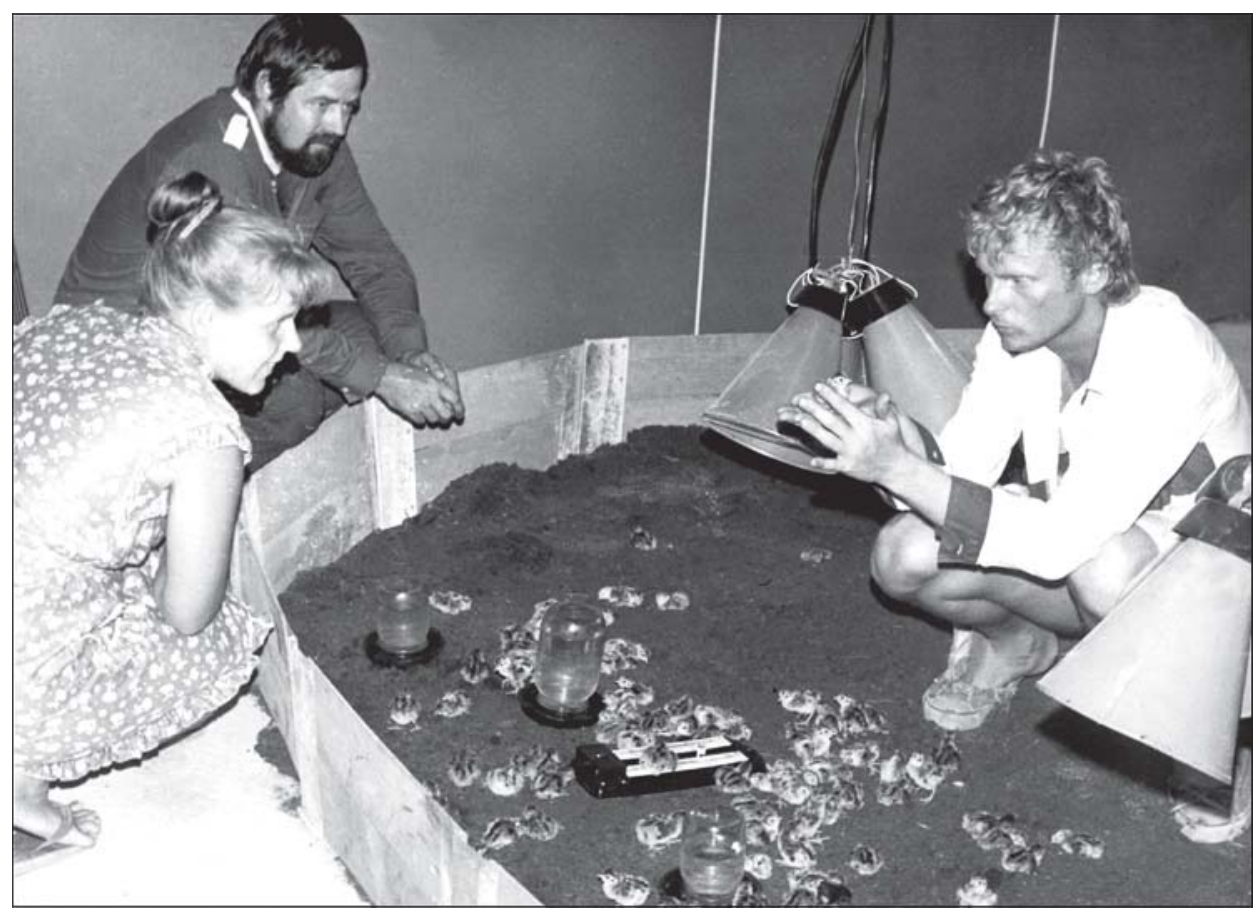

Foto 7. Tiina Zirnask, Ülo Siimets ja Heino Jürviste faasanitibudega. 1985.

tikuningat: 1930. aastatel Tartus, 1980. aastal Viljandimaal ja Sarus eelnimetatu, kelle leidis Mõniste valla talunik Rein Kõiv, kui läks oma 49 faasanile süüa viima. Aedikus, faasanite toidulaua juures nägi ta maa sees suurt auku, kus siples hulk rotte. Pealmised olid veel elus, alumised surnud. Sabasidpidi oli kokku jäänud 16 rotti.

Rottidega võitlemiseks ei näinud me Sinikülas muud võimalust kui jõusöödapunkri ehitamine. See on maapinnast 2-3 meetri kõrgusele metalljalgadele asetatud punker - rotid nimelt ei suuda mööda metalli ülesse ronida. Järgmisel aastal saime Sakala tõulinnukasvatussovhoosist jõusöödapunkri, aga seda ei jõutudki kohale panna. Kuid sellest hiljem.

Leedust saabus tagasi Heino Jürviste koos 300 tõulinnu ja 1000 tibuga. Auto lindudega jõudis kohale öösel ning H. Jürviste tahtis renditud auto ruttu vabaks lasta. Suur kilehoone oli vaheseinaga kaheks jagatud. Suured linnud lasti kastidest lahti ühte ja faasanitibud teise hooneossa.

Olin faasanifarmi hooldajateks tööle võtnud Tiina ja Gunnar Zirnaski. Kui nad järgmisel hommikul tööle tulid, et saabunud faasanitele süüa anda, selgus hirmus tõsiasi, et toodud tibud olid pimedas kuhjadesse kogunenud ja alumistesse kihtidesse jäänud faasanitibud olid kõik hukkunud. Põhjuseks 


\section{Ülo Siimets}

oli esiteks see, et kõik soojenduslambid ei olnud elektrivõrku lülitatud. Teiseks ei olnud katsetatud, mis juhtub siis, kui kõik soojenduslambid pikemaks ajaks sisse lülitada. Tehniliste tingimuste järgi oleks pidanud elektrienergiaga varustamine olema normaalne, tegelikkuses aga ei vastanud alajaama kaitsmed nõuetele, vaid olid liiga nõrgad ja kuumenesid üle. Pimeduses ja külmas püüdsid linnupojad üksteise vastu surudes ja üksteise peale ronides sooja saada. Nii tekkisid kuhjad. Tugevamad linnud ronisid ülespoole ja alumised lämbusid. Ellu oli jäänud umbes 300 faasanitibu, aga lähipäevadel surid nendest veel ligi pooled.

Õnnetus juhtus ka suurte lindudega. Ühe koha peal oli hoonet katva kile äär lahti. Kas see oligi ehitades lahti jäänud või oli keegi selle lahti rebinud, seda ei tea. Me ei osanud konkreetselt kedagi kahtlustada. Selge oli aga see, et paljud kohalikud olid Tartu Metsakombinaadi juhtkonna, seega eriti minu peale tigedad, et olin võtnud nende heinamaad faasanifarmi alla. Igatahes kubises farmiümbrus täiskasvanud faasanitest, kes olid hommikul, kui valgeks läks, roninud lahtise kileserva alt välja toitu otsima. Farmitöötajate jutu järgi oli linde välja pääsenud kakssada. Paljud õnnestus kinni püüda, paljud aga lendasid metsa. Järelejäänud linnud sorteeriti järgmisel päeval põhikarja hoonesse.

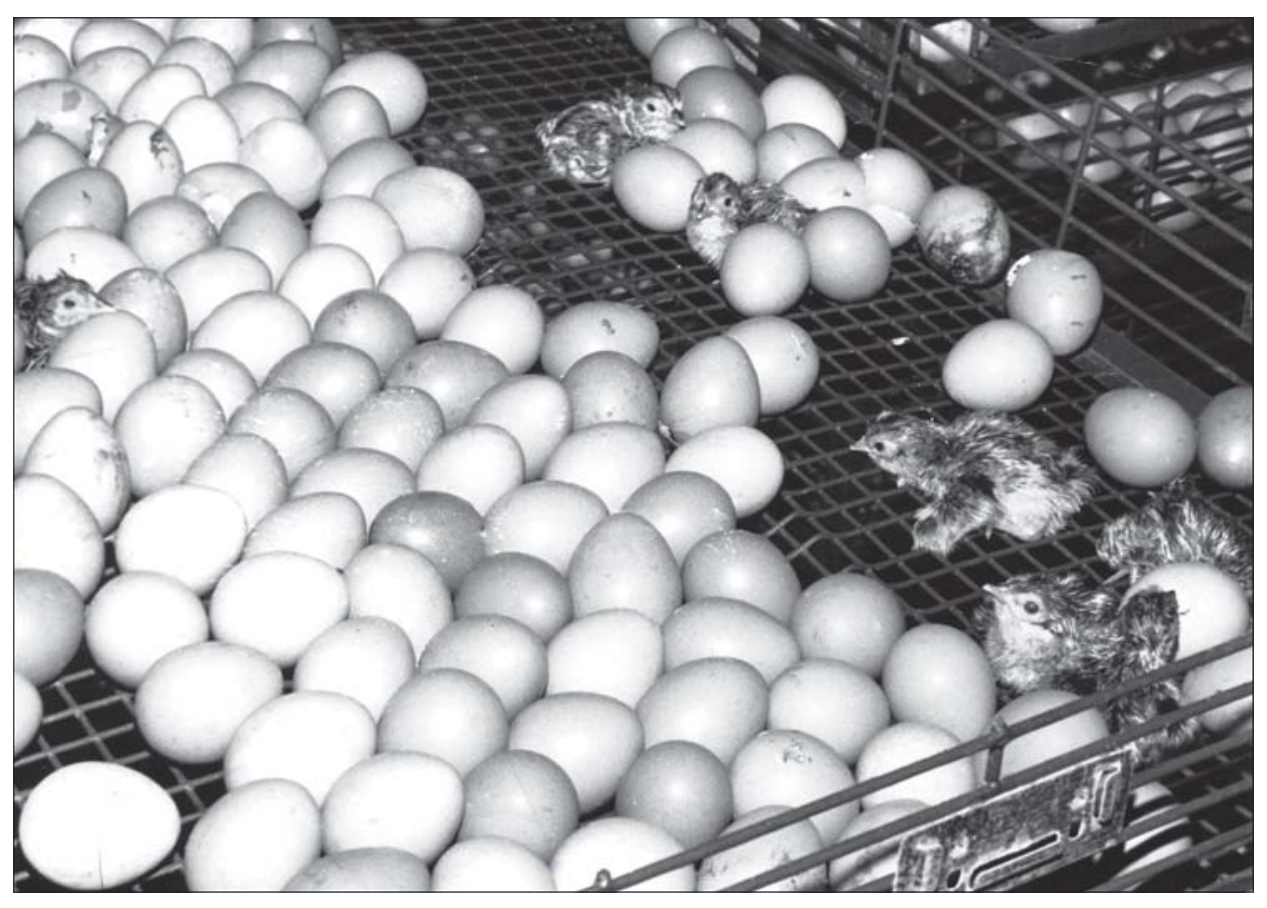

Foto 8. Faasanitibud koorumas. 1985. Heino Jürviste foto. 
Seega kaks suurt õnnetust korraga. 1300 faasanist jäi farmi alles umbes 100 täiskasvanud lindu ja tibudest ellu ainult 150 lindu, pooled neist pealegi kuked. See selgus muidugi hiljem.

Heino Jürviste käis veel kord Leedus ja tõi sealt juurde 100 emast faasanit. Leedus oli tekkinud küll täiendava linnupartiiga probleeme, aga osava asjaajajana, nagu $\mathrm{H}$. Jürviste seda oli, kasutas ta meie tuntud linnuteadlase nime palve esitamisel ja sai lisalinnud kätte. Linde toideti Sinikülas täpselt Leedu faasanikasvatajate õpetuse järgi. Eriti rõhutasid Leedu linnuteadlased vitamiinirikka, eelkõige E-vitamiini sisaldava toidu andmist. Suurendamaks munade viljastamist ja tibude koorumist lisatigi toidule E-vitamiini. See oli kallis, aga temast oli kasu. Täiskasvanud linnud munesid veel ligi 1200 muna ja me saime katsetada inkubaatorit.

Ootamatult oli munadest koorumise protsent väga kõrge (ligi 73\%) ja me saime juurde 870 tibu. Tibude kasvatamisel tekkis aga probleeme. Aeg-ajalt võttis maad kannibalism - suured ja tugevamad linnud tungisid nõrgematele kallale. Linnutalitajad tõstsid nõrgemad eraldi, aga tihti jäädi hiljaks ja faasanitibud olid juba liiga tugevalt vigastada saanud ning surid. 10-päevased tibud viidi edasi "noorte aedikusse". See oli kilega kaetud suur kasvuhoonetaoline ehitis, kust ilusa ilmaga oli võimalik lasta tibud jalutama võrguga kaetud alale. Vahel tekkisid siiski mõned lindude kuhjumised ja alumised faasanitibud hukkusid. Üldiselt kasvasid linnud hästi. Aga ka solaariumis puhkes aeg-ajalt kannibalism. Ellu jäi umbes 600 lindu.

Septembris valiti täiskasvanud lindude hulgast välja tugevamad isa- ja terved emalinnud. Saime oma karja juurde 200 emalindu. Korralikest kukkedest puudust ei olnud. Nii oli Tartu Metsakombinaadil 1986. aasta kevadeks olemas tõufaasanikari umbes 450 linnuga.

Faasaniliha realiseeriti nii värskete kui ka suitsetatud lihakehadena metsakombinaadi töötajatele hinnaga vastavalt 4,5 ja 7 rubla kilo.

Faasanifarmi kuulsus kasvas ilma igasuguse reklaamita. Siniküla hakkasid algul külastama kooliekskursioonid. Pärast lühikest saadet Eesti Televisioonis hakkas külalisi saabuma ka Tallinnast. Kohale tuli Viru hotelli direktori asetäitja majanduse alal. Nõukogude ajal oli Viru Inturisti hotell ja seal ööbisid põhiliselt välismaalased. Mees oli faasanitest nii vaimustatud, et pakkus võimalust sõlmima Tartu Metsakombinaadiga leping, et ära osta kogu tulevase farmi toodang. Ta oli nõus maksma 10 rubla puhastatud faasanirümpade kilost. See oli kõrge hind, arvestades, et sealiha kilo eest tuli välja anda 1,80 rubla. Pidasin seda lepingut esialgu varajaseks ja jäi jutt, et räägime sel teemal hiljem uuesti.

Farmi külastavad inimesed olid huvitatud ka faasanisulgedest. Heino Jürviste tegi faasanite pikkadest sabasulgedest pastapliiatseid. Need olid väga liht- 
sad, aga osteti ära nagu soojad saiad. Ta pani kõrvuti pastapliiatsi südamiku ja sabasule ning mässis sabasule alumisele osale alumiiniumfooliumi niiviisi ümber, et pastasüdamik kinnitus sule külge. Väga kiire ja odav lahendus. Neid müüs Heino huvilistele hinnaga 1 rubla tükk. Sabasulgedest oli tal pidevalt puudus. Suveniiriks korjati kaasa ka väiksemaid värvilisi faasanisulgi.

Külastajate rohkus tekitas mõtte teha faasanifarmi juurde linnupark. Heino Jürviste käis rääkimas Tallinna loomaaia direktori Mati Kaaluga, kes oli nõus andma meile loomaaia lindude munetud mune, et saaksime kollektsiooni jaoks linde välja haududa. Ta kinkis meile ka kaks kuldfaasanit ema- ja isalinnu. Nendele lindudele ehitasime spetsiaalse aediku inkubaatorihoone seina äärde. Kuldfaasani isakukk oli tõeliselt uhke oma kuldkollase pea ja pikkade punaste sabasulgedega. Ta oli külastajate alalise imetluse objektiks.

Heino Jürviste oli leppinud Mati Kaaluga kokku ka paabulindude kinkimises Siniküla faasanifarmile. Plaanis oli tuua linnud Sinikülla 1987. aasta kevadel.

Kusagilt oli Heino Jürviste lugenud, et kuningliku olemisega paabulinnud on India rahvuslinnud, olles samas ka päikese sümboliks, kusjuures isalinnu laialiaetud sabasulgedest kaar pidi tähistama taevakaart ja sabasulgedel olevad "silmad" taevatähti. Kui käisin 2005. aasta sügisel Nepalis Anapurnat vallutamas, vestlesin meie giidi Bibi Funyaliga, kelle ema oli hinduist, hinduismist ja budismist. Temalt kuulsin, et budismis tähistavad paabulinnu sabal olevad silmad valvsust, samas pidavat üksik sulg tooma õnnetust. Hinduistide sõjajumal Karttikeya pidada kasutama paabulindu oma sõjaratsuna.

Meil oli kavas kaevata farmi lähedale suur ringikujuline tiik, mille keskel oleks saar, ja tuua Sinikülla mitmesugused pardid, luiged ja muud linnud. Kaevatud tiiki tahtsime lasta kuldkalad. Kahjuks jäid need mõtted ainult unistuseks.

1986. aasta lõpuks suurendasime faasanite tõukarja 1000 linnuni. Kokku oli meil juba 3500 lindu. Siniküla külastasid kõrged külalised nii EKP Keskkomiteest kui ka Eesti NSV Ülemnõukogust. Sinikülla leidsid tee ka kõikide ministeeriumide esindajad alates osakondade töötajatest ja lõpetades ministriga. Inimesed olid huvitatud eksootilise linnuliha pakkumisest oma külalistele. Faasanid on ilusad linnud ja mitmed eelnimetatutest olid huvitatud ka elusate faasanite ostust.

Faasaniliha ja elusate lindude ostmisest olid huvitatud ka mitmed eraisikud. Siiamaani on meilt ostetud faasanite järeltulijad alles mitmel pool Eestis, näiteks Räpina kandis Soidla talus.

Farmi aiavõrgust välja lennanud linde püüdsid hulkuvad koerad. Olukord ei olnud Sinikülas tookord muidugi nii hull nagu 2000. aastal Raplamaal Härgla 
külas Raivo Riisi faasanifarmis. Seal ründasid kolm lähedalasuva Kaeramaa talu koera öösel faasanikarja. Kuigi penid lõhkusid farmi võrkaia ja murdsid maha 120 lindu, otsustas peremees karja taastada. Maaleht märgib ka, et Raivo Riis oleks sel aastal faasanikarjast hakanud tulu saama, aga nüüd oli rünnaku tõttu olukord nagu kaks aastat tagasi (Aitsam 2000).

1987. aastal oli kavas hakata faasaneid tõsiselt turustama. Käisin 1986. aasta sügisel Tallinnas Gagarini puiesteel asuvas metsamajandusministeeriumis minister Heino Tedre jutul. Arutasime 1987. aasta plaani alustada sügisel lindude müüki faasanijahiks metsamajanditele ja metskondadele. Ka Viru hotellile andsime lootust, et aasta lõpul võib tarneid alustada.

Kahjuks tahtis saatus teisiti.

\section{Kes tappis Siniküla faasanid?}

1987. aasta jaanuaris liideti Tartu Metsakombinaat Tartu Mööblikombinaadiga. Tekkis metstööstuskoondis Tarmeko. Põhjuseks oli, et Tartu Metsakombinaadil oli ette näha toodangu suurenemist umbes neli korda, aga Tartu Mööblikombinaadil erilist toodangu kasvu ei olnud. Seda heideti kolleegiumitel mööblikombinaadi juhile Olev Nigulile pidevalt ette.

Seni oli metsatööstuse minister olnud Narvas sündinud Vladimir Tšernošov, kes toetas igati metsakombinaate. Ka meeldis talle Tartu Metsakombinaadi otsus hakata tootma faasaneid ja faasaniliha. Ta oli üks väheseid ministeeriumis töötavaid venelasi, kes oli ära õppinud eesti keele. Kuigi kolleegiumil räägiti eesti keelt mitteoskavate venelaste ja muulaste suure hulga tõttu vene keelt, rääkis Vladimir Tšernošov metsakombinaate külastades alati eesti keelt. Ootamatult suri ta Võru Mööblikombinaati külastades saadud südameinfarkti tagajärjel. Metsatööstuse ministri tooli sai endale tšetšeen Sergei Fjodorovitš Zinani. Varem oli see mees juhtinud Tallinna Vineeri- ja Mööblivabrikut. Sergei Zinani oli ka EKP Keskkomitee liige. Tal olid suured tutvused Moskvas ja tema vend oli Nõukogude armee kindral. Hariduselt oli S. Zinani mööblitööstusinsener ja toetas jäägitult mööblikombinaate. Väga heades suhetes oli ta Tartu Mööblikombinaadi direktori Olev Niguliga, kes varustas teda ja ta sõpru odava mööbliga.

Tartu Metsakombinaadil oli mitmeid eesrindlike plaane, näiteks kõvasulamsaagide tsehhi rekonstrueerimine. V. Tšernošovi ajal toimusid juba läbirääkimised Rootsi metallifirmadega saagide tootmise joint venture'i (ühisettevõtte) loomiseks. Lõpuks jäi sõelale firma Sandvik. Käisin selle firma esindusega mitmeid kordi kohtumas. Sõlmisime esialgu nendega lepingu kõvasulamsaagide tootmispinkide saamiseks. 
Plaanis oli ka kahjumis töötava Tabivere alumises laos asuva taaratsehhi rekonstrueerimiseks nurga- ja katteliistude tsehhiks. Läbirääkimisi olid peetud juba kolm aastat ning lõpuks jõuti lepingu allakirjutamiseni. Tsehhi elektrivajaduse lahendamiseks olin organiseerinud projektid ja taotlenud raha Lähte-Tabivere 10-kilovoldise kõrgepingeliini ehituseks. Samuti oli Tabiverre taaratsehhi lähedale ehitatud uus kõrgepingealajaam. Tsehhi sisseseade pidi saabuma 1987. aasta aprilliks.

Sergei Zinani kutsus mind kui nende projektidega tegelejat 1986. aasta kevadel Tallinna. Mind ära kuulanud, tegi ta ettepaneku anda saabuv tsehhi sisseseade üle Tartu Mööblikombinaadile. Ma ei nõustunud. Ütlesin, et projekti elluviimiseks on kulutatud miljoneid rublasid ja sellele projektile on läinud minu mitme aasta töö ja aeg. Sõitsin Tartusse tagasi.

Mõne aja pärast tulid esimesed kurvad uudised. Hakatuseks rääkis S. Zinani igal kolleegiumil, kuhu olid kutsutud kõik Eesti metsatööstuse juhid: "Siimets on utopist, tahab kapitalistide-rootslastega ühisfirmat teha. Kas pole naljakas, suurim metallitootja Nõukogude Liit hakkab metalli sisse vedama Rootsist?" Püüdsin oma vastukõnedes väita, et kõvasulam läheb meie suurel kodumaal sõjatööstusesse ja tavafirmadele seda lihtsalt ei eraldata. S. Zinani naeris mu välja ja mind saadeti Moskvasse NSV Liidust kõvasulami saamise võimalusi uurima (see on mõistagi juba omaette teema).

Teiseks kurvaks uudiseks oli, et Tartu Metsakombinaadi kõvasulamsaagide tsehhile ette nähtud tööpingid saabusid, kuid viidi ja pandi ülesse Tallinna Vineeri- ja Mööblikombinaati. Nagu ütles S. Zinani: "See on Eesti suurim puiduettevõte ja neile on neid pinke rohkem vaja."

Mõned kuud hiljem kutsuti mind ministri juurde. Sergei Zinani oli välja mõtelnud nipi, kuidas saabuvad puidupingid Tartu Mööblikombinaadile anda.

Ta ütles: "Siimets, sa tahtsid metsakombinaadi toodangut suurendada. Selleks ei ole vaja rootslastega koostööd teha. Sul on kolm kuud aega. Rebase tänavas on Niguli vana tühi tsehh. Sellest on vaja teha metsakombinaadi abitootmisliin. Hakkate tootma madratseid. Õmblusmasinad saad Narva mööblikombinaadist. Kui sa mulle kolme kuu pärast raporteerid, et esimene madrats on valmimas, on Saksa liin sinu."

See oli käsk nagu muinasjutus. Tavalise projekteerimise peale läks juba minimaalselt pool aastat.

Mis mul teha? Käisin tutvusin Narva mööblikombinaadi madratsitsehhiga. Tulin tagasi. Visandasin paberile skitsi, kuidas saaks Rebase tänava lagunenud hoonest teha madratsitsehhi. Paralleelselt hakkas metsatööstuse konstrueerimisbüroo projekti paberile kandma. Lubasin meestele maksta kiirtöö eest eritasu ja seda ma ka tegin. Kõik metsakombinaadi ehitajad suunasin Rebase tänava tsehhi ehitusele. Juurde võeti veel ajutisi ehitustöölisi. Õhtul 
ja öösel töötas tudengite must malev. Töötati ka laupäeval ja pühapäeval. Kolm päeva enne kolmanda kuu lõppu helistasin ministrile ja kutsusin ta Rebase tänavasse tsehhi avamisele ja esimese madratsi väljalaskmisele. Kuuldes uudist, karjatas S. Zinani torru: "See on võimatu". Vastasin, et võimatu küll, aga tsehh on valmis ja toodang tuleb.

Sergei Zinani saabus kohale. Vaatas tsehhi üle ja ütles: "Siimets, sa oled tõestanud, et te saate uue tsehhiga hakkama ja me anname ta sulle."

Tegelikult murdis mees oma sõna.

1987. aasta jaanuaris, kui olin Tallinnas ministeeriumis, sain sõpradelt kuulda ootamatut uudist: Tartu Metsakombinaat liideti Tartu Mööblikombinaadiga. Otsus oli tehtud tagaselja juba kaks nädalat tagasi. Meid ei kutsutud isegi sellele nõupidamisele.

Nagu Tallinnas metsatööstusministeeriumis räägiti, olla kaks sõpra-seltsimeest Sergei Zinani ja Olev Nigul istunud koos saunas ja seal välja mõtelnud, kuidas metsakombinaadile saabuv tsehh Tartu Mööblikombinaadile üle anda. Kahe ettevõtte baasil moodustati Metsatööstuskoondis Tarmeko. Ma ei hakka nendest sündmustest pikalt kirjutama.

Algasid rekonstrueerimised. Tootmisnõupidamised hakkasid toimuma Olev Niguli juures endise mööblikombinaadi nõupidamiste saalis. Raha kasutati sealse juhtkonna äranägemisel. Ma läksin tootmisdirektor Eino Pürgi juurde, et saada luba faasanitele E-vitamiini osta. E. Pürgi jutt oli lühike: "Kasvatage pulle, nemad söövad heina ega vaja mingeid vitamiine."

Järgmisel tootmisnõupidamisel rääkisin:

"Tartu Metsakombinaat on likvideeritud. Suunake osa inimesi, kes on tulnud Sõbra tänava kaadriosakonda, metsa vaigutajaks. Algab vaigutushooaeg ja sinna on inimesi juurde vaja. Teiseks on vaja osta Siniküla faasanifarmile E-vitamiini. Muidu linnumunad ei viljastu ja koorumine on raskendatud."

Selle peale hakkas nõupidamislaua otsas istuv Olev Nigul karjuma: "Kuule, Siimets, kas sa arvad, et meid on pandud siia ametisse selleks, et teid aidata. Meid on pandud ametisse selleks, et me raudora punaseks ajaksime ja teile persse pistaksime, et te paremini töötaksite. See on meie abi teile.”

Vastasin, et sellise abi puhul jääb vaigutusplaan jääb täitmata ja Sinikülas toodetakse ainult mädamune.

"See on loll jutt. Plaanid tuleb täita."

Nii jäigi. Abi ma ei saanud. Oma raha eest ma muidugi ka vitamiine ostma ei hakanud - nii palju mul raha ei olnudki. Vaigutusplaan jäigi täitmata. Siis kutsuti vaigutusmeister välja ja tehti talle käskkirjaga noomitus.

Siniküla faasanid munesid arvestatud plaanilise 21000 muna asemel 28000 muna. 
Kahjuks oli ka nende viljastumisprotsent madal. Munadest koorus alla 10 protsendi linde. Koorumisega oli linnupoegadel raskusi. Vaesed linnupojad olid nõrgad ega suutnud ennast isegi munakoorest vabastada. Talitaja Tiina kuulas aegajalt inkubaatori juures ja kui kuulis piuksumist, tegi ukse lahti ja aitas linnupojal koorest vabaneda. Kuid linnupojad olid ikkagi nõrgad ja paljud neist surid. Siiski oli meil 1987. aasta sügiseks umbes 4500 lindu, sellest paar tuhat tõufaasanid. Oli vaja juurde ehitada teine samasugune farmipool, nagu oli valmisolev, sest lindude hulk aedikus oli lubatust kaks korda suurem. Siis oleks olnud võimalik toota järgmisel, 1987. aastal vähemalt 40000 lindu.

Läksin jälle Olev Niguli juurde raha küsima. Tema pahandas: "Mitte midagi te ei saa. Toodate Sinikülas mädamune. Kellel seda vaja?”

Järgmisel nõupidamise karjus O. Nigul, et need metsakombinaadi omad on ikka lollid. Oleksid võinud lasta talunikel pulle kasvatada, nagu mööblikombinaat tegi. Talunikule maksad suve jooksul koristaja palga ja muud ei olegi vaja. Abimajand toimiks ja plaan oleks täidetud. Kõik oleksid rahul. Aga need lollid kasvatavad faasaneid ja toodavad mädamune.

Vaatamata minu jõupingutustele ei olnud E. Pürgi ja O. Niguli jutul käimistel tulemusi. Püüdsin selgitada E-vitamiini tähtsust lindude viljastumisele ja võtsin kaasa isegi Saksa linnukasvatajate raamatu, et seda ülemustele näidata, aga nad ei hakanud seda vaatamagi. Eesti metsades faasanite taaselustamine ei huvitanud kedagi. Pakkusin ennast ise faasanifarmi juhatajaks, aga Olev Niguli ja Eino Pürgi arvamus oli, et farm tuleb likvideerida. Rääkisin järjekordselt Siniküla perspektiivplaanidest, külastajatele vaatamisväärsuse loomisest, Eesti looduse rikastamisest uue linnuliigiga, lepingust Viru hotelliga, kes on nõus kalli raha eest kõik linnuliha ära ostma, aga ka see ei huvitanud kedagi.

"Me ei ole mingi linnukasvatusettevõte, veel vähem loomaaed," ütles Olev Nigul. Eriti ajas teda närvi väide, et EKP Keskkomitee ja Eest NSV Ülemnõukogu on ka faasanitest huvitatud.

"Mind nad ei huvita," karjus Olev Nigul.

Jäi mulje, et ainsaks põhjuseks lindudest lahti saada oli Siniküla faasanifarmi liiga suur kuulsus ja see, et E. Pürg ja O. Nigul ei olnud seda ise välja mõtelnud.

1987. aasta sügisel antigi käsk linnud tappa. Mina andsin lahkumisavalduse ja läksin tööle Elva Metsamajandisse.

Mis sai Eesti faasanikasvatusest edasi?

Likvideeritavast Siniküla faasanifarmist ostisid linde mitmed metsamajandid. Üks suurimaid ostjaid oli Järvamaa Metsamajand, kes ostis 1987. aasta lõpul 300 tõufaasanit. Kabala metskonnas töötas ja töötab siiani metsaülema- 
na Elor Ilmet. Isa Kaupo Ilmeti eeskujul, kes pidas Aakre metskonnas faasaneid, oli poeg nõus need linnud oma metskonda vastu võtma ja ta ehitas faasanitele võrguga kaetud tarandiku.

1989. aastal oli külm ja lumerohke talv. Raske lumi lõhkus võrgud ja linnud pääsesid metsa. Neid ei hakatud enam kinni püüdma. Loodeti, et nad aklimatseeruvad. Neile viidi liiva ja lisatoitu. Mitmeid aastaid oli vabaduses linde näha, aga praeguseks on kõik kadunud.

Et ma ei töötanud enam metsatööstuskoondises, ei saanud ma andmeid, kuhu veel linde müüdi. Farmitöötajad ütlesid, et nende mäletamist mööda viidi linde veel Saaremaale ja Läänemaale ning isegi Pihkva oblasti metsamajandid olnud lindude ostmisest huvitatud ja osa elusaid faasneid olla müüdud neile.

\section{Faasanikasvatusest Eesti Vabariigis}

\section{Milline on faasanikasvatuse olukord Eesti Vabariigis?}

Vastust sellele küsimusele püüdsin ma leida ajakirjandusest ja internetist. Andmeid oli suhteliselt vähe.

Ojapere talu Lasva vallas kasvatas perehobina teiste lindude hulgas faasaneid (Võrumaa Talupidajate Liidu Infoleht 1993).

Kaupo Ilmet alustas põhimõtteliselt samasuguse loomapargi rajamist, nagu tal oli olnud Aakres, 1996. aastal Elistveres. Loomapark on käesolevaks ajaks on kujunenud Lõuna-Eesti ja kogu ümbruskonna populaarseks külastuspaigaks.

27. oktoobril 1998 otsustas Eesti Vabariigi valitsus arvata küttida lubatavate ulukite hulka faasanid. Eelnõu selleks valmistas ette keskkonnaministeerium Eesti Jahimeeste Seltsi ettepanekul. Sellel kuupäeval oli Eestis registreeritud kaks faasanifarmi (Eestis võib peagi faasaneid jahtida, 1998). Faasaneid lubati küttida 1. oktoobrist kuni veebruari lõpuni. Selle määruse vastuvõtmisest alates hakkas suurenema faasanite pidamine ja ka nende arv Eestis.

15. septembril 2000 teatas Eesti Päevaleht, et Eesti Põlevkivi peadirektor Mati Jostov tasub Põlva lähedal asuva faasanifarmi ülapidamise kulud. Lindude eest hoolitseb tema sõber ja neid kasvatatakse jahi tarbeks metsa lahtilaskmiseks. Karjas on umbes 100 faasanit (Odres 2000). Vestlesin ise praeguseks juba manalamehe Mati Jostoviga faasanitest 2006. aastal Järvselja Jahimeeste Seltsi aastakoosolekul Tartus. Ta andis oma farmi kohta segast teavet ning ütles, et sõber tegeles jah, aga ega tal endal enam erilist huvi asja vastu ei ole. 
8. augustil 2000 kirjutas Viljandi ajaleht Sakala, et Navesti jõe ääres peab faasaneid Kalev Võitla. Mees olla hankinud linnud Juurus ja Varbolas asuvatest faasanifarmidest. Munejaid linde oli karjas 35 ja kevadel oli saadud faasanitelt 1800 muna. Tibud hauti välja pooltest munadest. Kirjas on, et Kalev Võitla tahab kasvatada 200-300-pealise tõukarja. Tulevikus kavatseti osa linde kodu lähedale metsa aedikusse lahti lasta, kus nad hakkavad omaette sigima. Linnukasvataja hinnangul läheb ühe linnu kasvatamine maksma umbes 100 krooni. Saabuval sügisel oli tal plaanis hakata rahakatele jahihuvilistele pakkuma aristokraatlikku faasanijahti ja kutsuda jahituriste, kellele jaht maksaks 240 krooni. Võimaldataks tulla jahile koos oma koeraga. Eesti jahimees saaks lastud linnud endale, välismaalastele see privileeg ei kehtiks (Seil 2000). Sama pealkirjaga lugu "Suure-Jaani metsades hakkavad elama faasanid" on viitega Sakalale ja MEGA-le ära toodud ka Eesti Päevaleht Online’is (Sakala \& MEGA 2000).

Aasta hiljem teatas Sakala, et kaks nugist ründasid paar nädalat tagasi metsa rajatud faasaniaedikus linde ja murdsid kõik faasanid maha. Nugiste ohvriks langes 15 lindu.

Kalev Võitla oli $180 \mathrm{~m}^{2}$ suuruse aediku rajanud aasta varem. Mees ise väitis, et linnud peavad kolm põlvkonda metsas elama, alles siis hakkavad nad seal munele. Aediku lähedale oli kohaliku jahiseltsi ja selle esimehe Ilmar Pommeri abil ülesse pandud kiskjate (rebased, kährikkoerad) püünised. Kui rebased jäid rajatud aediku taha, siis nugised ronisid posti mööda üles, närisid võrgu läbi ja tapsid kõik faasanid.

Kalev Võitla ei loobunud lindude aklimatiseerimise ideest, vaid tahtis rajada 12 ha suuruse aediku. Ümbruskonna maa kuulus aktsiaseltsile Roger Puit. Firma juht Margus Meimer toetas K. Võitla projekti. Aedikute rajamise maksumus oli esialgsetel hinnangutel 120000 krooni, millest Viljandi keskkonnateenistus andis ürituse toetusena 40000 krooni. 2000. aasta sügisel oli Kalev Võitlal 700 lindu. Talvel korraldas ta jahituristidele kuus faasanijahti (Seil 2001). Nugiste rünnaku faasanitele edastas ka SL Õhtuleht. Loo sisu on sama, mis Sakalas, ainult faasanite arvuks oli öeldud 24 (Jakobson 2001).

Kalev Võitla jätkas faasanite kasvatamist. Tema farmi põhikarja 90 kana elas möödunud aastal kaheksas aedikus. Igas aedikus oli mitu erksavärvilist kukke. Linnukasvataja teatel asusid faasanifarmid sel ajal veel Rapla maakonnas Mahtras ja Läänemaal Varbolas (Kaldma 2005).

Jõgevamaal Pajusi vallas Lahaveres kasvatas Soo-otsa talu peremees Aare Metting oma majapidamiseks faasaneid, et hakata tegelema jahiturismiga (Tähismaa 2001).

Saaremaa Kaarma valla Keskranna küla Keskranna talu koeratoitu tuli 2001. aastal sööma tundmatu, kanast veidi väiksem ilus lind, kes osutus 
jahifaasaniks ja oli ilmselt pärit Uno Vaiti faasanikasvandusest. 20. jaanuaril tellisid Saaremaa jahikliendid Kuresaare jahipiirkonnalt faasanijahi 150 linnule. Ühe linnu jahiks lahtilaskmine maksab 180 krooni. Kolmandik jahiks vabastatud lindudest lasti maha, ülejäänud pääsesid pakku. Arvatavasti oli koeratoitu sööma tulnud faasan üks vabadusse jäänud lindudest. Ka eelmisel aastal oli 100 vabadusse lastud linnust kätte saadud üks kolmandik. Riigimetsa Majandamise Keskuse Lääne-Saarte regiooni juhataja Uno Vaiti andmetel on linde jahiks lahti lastud juba neli aastat (Kuivjõgi 2001). Sama uudise edastasid ka teabeagentuur ETA ja Eesti Päevaleht Online (ETA 2001).

Ka Arvo Kirsi talus on võimalik faasanijahti pidada. Tema kirjeldab omapärast juhtumit, kus jahile tulnud ärimees sidus lahtilastavale faasanile 500kroonise jala ümber. Linnu tabaja pidi selle preemiaks saama. Lind lasti koos teistega vabadusse, kätte teda ei saadud. Paar päeva hiljem tuli faasan ise farmi juurde toitu otsima. Käis hoovil ringi, jalg sirge nagu lahases. Hoovilt sai peremees faasani koos jala küljes oleva kingitusega kätte (Hagelberg 2002).

Teateid faasanikasvatajatest on veelgi. 2002. aasta oktoobris kirjutas Vallo Nuust Tartu Postimehes Saare valla koduloomaaiast, kus elavad pardid, kanad, haned, faasanid, kitsed, lambad, sead, vasikas, koerad, kassid ja hobune (Nuust 2002). Naisteajakirja Stiil 2002. aasta detsembrinumbris portreteerib Margit Kilumets Kalev Jalastost, kes peab Torma valla Linnuse talus mh faasaneid jahiturismi arendamiseks. Talunik on ostnud ära ka Reastvere linnusekoha, kus tahab taastada linnuse ja pakkuda eesti toitu (Kilumets 2002). Anne Mišina kirjutab maakonnalehes Hiiumaa, et 2003. aasta Kurista mihklilaadal jäid kahjuks sobiliku puuri puudumise tõttu eksponeerimata Indrek Pisa õuel kasvatatud faasaneid (Mišina 2003). Faasanid toodi 23.-25. juulini 2004 Kuutsemäel peetud kuldsete retriiverite suvepäevadele - nende abil õpetati koeri lindu tooma (vt Kuldsete suvepäevad 2004). Faasanid olid väljas ka 2004. aastal Põltsamaa 15. linnulaadal (Saveli 2004).

Faasaneid on peetud teiste lindude kõrval ka Pärnumaal Audru vallas Pihlaka talus. Talu perenaine Katrin Pirs on 2005. aasta suvel Maalehe ajakirjanikule Silja Lättemäele kahetsedes öelnud, et nende faasanid on metsa põgenenud, pererahvas üritab neid küll suure liblikavõrguga püüda, kui uhked linnud käivad hommikuti taluõuel toitu nokkimas, ent tulutult. Samas mainis perenaine ajakirjanikule, et kavatseb tallu uued faasanid tuua (Lättemäe 2005).

Eksootilist linnuparki rajab Valeri Kostin Võrumaale Lasva valda Jaaniraotu tallu. Muu hulgas ujuvad sel tiigil mustad luiged, aedikus aga jalutavad 
nandud ja rohefaasanid. Kasvanduses võib kohata teisigi faasaneid, parukpärlkanu, paabulinde jne (Päärt 2005).

Liigirikas kodulindude ja kanaliste kogu on Õpetajate Lehe andmetel olnud ka lilleseadjana kuulsaks saanud Erkko Liivil. Selles oli üheksat tõugu kanu, paabulinnud, faasanid, haned, pardid ja papagoid (Järve 2001). Mõniste vallas Saru külas Alaveskil asuvasse tallu plaanib talunik Rein Kõiv rajada midagi Elistvere loomapargi sarnast. Kuid talus kasvatatakse jahiturismi eesmärgil ka metssigu ja faasaneid (Kabun 2006).

Jahindusalase veebisaidi Jääger-Online foorumis pakuti näiteks 2006. aasta 29. jaanuaril võimalust jahtida Keila lähedal farmis kasvavaid faasaneid: linnu hinnaks arvati esialgu 150 krooni (Jääger-online jahindusfoorum > Üldfoorum 2006).

Eesti Statistikaameti andmetel kasvatati 2003. aastal Eestis faasaneid 15 farmis. Tõukarja suuruseks kokku on 892 lindu (Viltrop 2005: 3). Tegin järelepärimise ka veterinaar- ja toiduametile faasanite arvu ning keskkonnaministeeriumile faasanite küttimise kohta Eestis. Esimesele küsimusele vastas loomatervishoiu ja loomakaitse osakonna juhataja Enel Niin, teisele keskkonnaministeeriumi peaspetsialist Kaarel Roht. 2005. aasta kohta antud andmed kajastuvad tabelis 1 .

Tabel 1. Faasanite arvukus ja küttimine Eestis 2005. aastal veterinaar- ja toiduameti ning keskkonnaministeeriumi andmetel

\begin{tabular}{l|c|c|c|c}
\hline Maakond & Faasaneid & Karju & $\begin{array}{c}\text { Karja keskmine } \\
\text { suurus }\end{array}$ & $\begin{array}{c}\text { Faasanite } \\
\text { küttimine }\end{array}$ \\
\hline Harjumaa & 423 & 2 & 21,5 & - \\
\hline Hiiumaa & - & - & - & - \\
\hline Ida-Virumaa & 7 & 1 & 7 & - \\
\hline Jõgevamaa & 20 & 5 & 4 & - \\
\hline Järvamaa & 13 & 1 & 13 & - \\
\hline Läänemaa & - & - & - & $\mathbf{6 3}$ \\
\hline Lääne-Virumaa & 93 & 3 & 31 & - \\
\hline Põlvamaa & 36 & 2 & 18 & $\mathbf{1 5 1}$ \\
\hline Pärnumaa & 83 & 7 & 11,86 & - \\
\hline Raplamaa & 65 & 2 & 32,50 & $\mathbf{1 3 6}$ \\
\hline Saaremaa & 49 & 5 & 9,8 & - \\
\hline Tartumaa & 128 & 6 & 21,33 & - \\
\hline Valgamaa & 149 & 5 & 29 & $\mathbf{3 3 7}$ \\
\hline Viljandimaa & 405 & 2 & 202,5 & - \\
\hline Võrumaa & 422 & 3 & 140,67 & $\mathbf{6 8 7}$ \\
\hline KOKKU & $\mathbf{1 8 9 3}$ & $\mathbf{4 4}$ & $\mathbf{4 3 , 0 2}$ & \\
\hline
\end{tabular}


Seega on faasanikasvatus Eestis võrreldes 2003. aastaga näidanud kasvutendentsi ja suurenenud 2,12 korda ehk 892-lt 1893 linnule. Faasaneid pidavate inimeste arv on aga kasvanud paari viimase aastaga 15-lt 44-le (1998. aastal oli vaid kaks farmi).

Siiski peetakse faasaneid põhiliselt lemmiklinnuna kodutalu kaunistamiseks. Enamikus karjades on alla 30 linnu. Suuremaid faasanifarme on Eestis ainult neli. Need kasvatavad linde ka jahimeestele müümiseks. Eesti Jahimeeste Seltsi direktor Andres Lillemägi ütles siinkirjutajale, et väikekiskjate (rebased, kährikud) suure arvu tõttu (nende arvukuse reguleerimist praegune jahindusolukord ei soosi) ei ole faasanikasvatusel lindude loodusesse laskmiseks Eestis perspektiivi. Tema jutu järgi hävitavad loodusesse lastud faasaneid kiiresti ka Eestist rännetega üle lendavate kulliliste parved. Eesti Jahimeeste Selts oli teinud katse ja lasknud metsa lahti 200 faasanit. Kuu aja pärast jahile tulles leidsid nad eest ainult suletuttide hunnikud ja üksikud ellujäänud linnud. Kuid lihatootmiseks ja lindude müümiseks jahimeestele faasanijahiks on arenguvõimalusi.

Helistasin ka Raplamaa faasanikasvatajale Raivo Riisile, kes pidas seniseid faasanijahte õnnestunuteks, sest jahimehed on küttinud $70 \%$ metsa lahti lastud lindudest.

\section{Kokkuvõtteks}

Viimastel aastatel on vahepeal Eestist kadunud linnuliigi - faasanite - arvukus hakanud aeglaselt kasvama, seda küll ainult farmides. Looduses faasaneid praktiliselt ei ole, sest olukord on lindudele ebasoodne. Moest on kadunud kähriku- ja rebasenahad ning seetõttu jahimehed neid eriti ei küti. Väikekiskjad paljunevad piiramatult ja hävitavad loodusesse lastud faasanid. Sama teevad ka kullilised.

Faasanifarmide arv on kasvanud 44ni. Enamik farme kasvatab faasaneid lemmiklindudena oma talu kaunistamiseks, turistidele näitamiseks ja vähesel määral söögiks. Jahimeestele müügiks ja jahiks kasvatavad faasaneid neli farmi. 2005. aastal oli Eesti farmides 1893 faasanit.

Ometi ei ole terves Eestis saavutatud sellist mastaapi, nagu seda oli Tartu Metsakombinaadi Siniküla faasanifarmis, kus 1986. aasta lõpus oli karja suurus 4500 lindu. Tartu Metsakombinaat liideti 1987. aastal Tartu Mööblikombinaadiga ja moodustati metsatööstuskoondis Tarmeko. Uue ettevõtte juhtkond eesotsas peadirektor Olev Niguli ja majandusdirektor Eino Pürgiga pidas faasanifarmi ebaoluliseks. Vaatamata sellele, et Siniküla farm saavutas läbi raskuste kavandatud suuruse ja täitis ülesande, oli Tarmeko juhtkonna 
Ülo Siimets

eesmärk üks - linnud hävitada. Ei tahetud kuuldagi looduse rikastamisest uute jahilindudega ja faasanipopulatsiooni taastamisest Eestis. Olev Nigul andis korralduse linnufarm likvideerida. Osa tõukarja linde müüdi metsamajanditele, enamik aga pärast tapmist lihana eraisikutele, põhiliselt Tarmeko töötajatele. Toored lihakehad müüdi hinnaga 4,5 rubla kilo, suitsetatud lihakehad 7 rubla kilo.

Faasanikasvatus on aga oma marginaalsuse, eksootilisuse ja atraktiivsusega paelunud kõigil aegadel inimeste ja meedia tähelepanu. Isikliku kogemuse lood ja meediatekstid, samuti tõsielufaktid moodustavad huvitava pärimusmaastiku, mis seostub nii kohapärimuse, perepärimuse kui ka jahimehejuttudega. Siniküla farmi loomine, tegevus ja selle likvideerimise asjaolud, samuti sundus asutada tootmisettevõtete juurde nn abimajandid, on aga 1980. aastate nõukogude majandus- ja juhtimissüsteemi väike mudel.

\section{Kirjandus}

Aitsam, Viio 2000. Faasanikasvataja taastab farmi. Maaleht, 23. veebruar (http://www. maaleht.ee/LEHT/2000/02/23/uudised.html - 11. august 2006).

Eestis võib peagi faasaneid jahtida, 1998. Eesti Päevaleht, 27. oktoober (http://www. epl.ee/?artikkel=43022 -11 . august 2006).

ETA 2001. Jahifaasan tuli taluõuest toitu otsima. Eesti Päevaleht Online, 6. veebruar (http://www.epl.ee/?artikkel=145078 - 12. august 2006).

Gladkov, Nikolai \& Dementjev, Georgi \& Mihhejev, Aleksei \& Inozemtsev, Aleksandr 1980. Linnud. Loomade elu 6. Tallinn: Valgus.

Hagelberg, Tõnu 2002. Suur ja lai on Martna vald. Maaleht, 17. jaanuar (http://www. maaleht.ee/?old_rubriik=3971\&old_num=745 - 12. august 2006).

Hann, Chris M. (toim) 1998. Property Relations: Renewing the Anthropological Tradition. Cambridge: Cambridge University Press.

Hinnosaar, Tõnu 2000-2001. Kohtumised Prillapatsil. Tõnu Hinnosaare kodulehekülg (http://kodu.neti.ee/ tonu/aloodus.html - 10. august 2006).

Jakobson, Kadri 2001. Verejanus nugised murdsid faasanikarja. SL Õhtuleht, 31. märts (http://www.sloleht.ee/index.aspx?id=104489 - 12. august 2006).

Järve, Linda 2001. Meisterflorist loob fantaasiamaailma. Õpetajate Leht, 16. november (http://www.opleht.ee/Arhiiv/2001/16.11.01/koik.shtml - 12. august 2006).

Jääger-online jahindusfoorum > Üldfoorum 2006. Jääger-Online (http://www.marandi. fie.ee/foorum - 12. august 2006).

Kabun, Kaile 2006. Fotosessioon ilvestega. Võrumaa Teataja, 21. jaanuar (http:// vorumaateataja.ee/?a=uudised $\& b=3980-11$. august 2006 ). 
Kaldma, Helgi 2005. Koidu talu kasvatab faasaneid ja põldpüüsid. Sakala, 7. juuni (http://sakala.ajaleht.ee/070605/esileht/artiklid/5016328.php - 11. august 2006).

Kilumets, Margit 2002. “Tahan olla vaba!”. Stiil 12 (detsember), lk 16-20.

Kononenko, Elina 2005. Saru külas leiti rotikuningas. Võrumaa Teataja, 12. märts (http://vorumaateataja.ee/?a=uudised $\& b=2542-11$ august 2006).

Kuivjõgi, Veljo 2001. Jahifaasan tuli taluõuest toitu otsima. Meie Maa, 6. veebruar (http://www.saarlane.ee/uudised/arhiiv/2001/02/06/3313/ - 12. august 2006).

Kuldsete suvepäevad, 2004. Kennel Meiepere: Kuldsed retriiverid (http://www.meiepere. ee/U240704.htm - 12. august 2006).

Lättemäe, Silja 2005. Kalkun Jossifit ei maksa karta. Maaleht, 14. juuli (http://www. maaleht.ee/?page=\&grupp=artikkel\&artikkel=3273 -12 . august 2006).

Mišina, Anne 2003. Mihklilaadal läks müügiks kõik. Hiiumaa On-Line, 23. september (http://hiidlane.elkdata.ee/index.php?arhiivi=\&idc $=10110131000146271000 \&$ PHPSESSID=68f15e1dd3be243acee75959e2a7965d -2 . august 2006).

Nuust, Vallo 2002. Loomaaed põhjustas Saare vallas valimistüli. Tartu Postmees, 30. oktoober (http://vana.www.postimees.ee/index.html?number=645\&op=lugu\&id=77258 12. august 2006).

Odres, Elo 2000. Mati Jostov hingelt metsamees. Eesti Päevaleht, 15. september (http:// www.epl.ee/?artikkel=120145 -11 . august 2006).

Podekrat, Maris 2005. Prangli kaitseingel. Eesti Päevaleht, 30. juuli (http://www.epl.ee/ ?artikkel=297403 -11 . august 2006).

Päärt, Villu 2005. Talumees rajab eksootilist linnuparki. Postimees 7. oktoober (http:// www.postimees.ee/071005/esileht/siseuudised/179369.php - 12. august 2006).

Sakala \& MEGA 2000. Suure-Jaani metsades hakkavad elama faasanid. Eesti Päevaleht Online, 8. august (http://www.epl.ee/?artikkel=115409 - 12. august 2006).

Saveli, Olev 2004. Hea lugeja! Tõuloomakasvatus 3 (september), lk 1 (http://www.eau.ee/ $\sim \mathrm{vl} /$ touloom/3_04.html - 12. august 2006).

Seil, Liisi 2000. Suure-Jaani metsades hakkavad elama faasanid. Sakala, 8. august (http://vana.www.postimees.ee:8080/sakala/display.cgi?k=2000-08-08\&f=faasanid\#0 12. august 2006).

Seil, Liisi 2001. Nugised tegid metsikus faasaniaias puhta töö. Sakala, 30. märts (http:// vana.www.postimees.ee:8080/sakala/display.cgi?k=2001-03-30\&f=faasanid\#2 - 12. august 2006).

Tähismaa, Inno 2001. Jõgevamaal kasvatatakse küttimiseks faasaneid. Äripäev Online, 8. jaanuar (http://www.aripaev.ee/mod/emb/online.html?disp=2\&uud_id=8161\&tyyp= \&leht_id=1836 - 12. august 2006).

Viltrop, Arvo 2005. Faasanite tervishoid. Lindude haigused (http://www.eau.ee/ viltrop/ faasanid.pdf - 12. august 2006).

Võrumaa Talupidajate Liidu infoleht 3 (49) (mai) 1993. 


\section{Summary}

\section{Recollections about Breeding Pheasants in Estonia. The Formation and Liquidation of Siniküla Pheasant Farm}

\section{Ülo Siimets}

Key words: home farms, pheasants, pheasant breeding, game bird breeding, hunting, media text, forest-keeping

The article provides an overview of the history of pheasant breeding in Estonia. A more detailed account is given on the foundation, activity and closing down of the Siniküla Pheasant Farm, which was active as a home farm of the Tartu Wood Plant and was the largest of such farms in Estonia at all times. The article is based on personal recollections, information about pheasants published in newspapers and in the Internet, interviews with former workers of the pheasant farm, game hunters and other people involved or knowledgeable in pheasant-breeding. Pheasants were formerly bred at estates, for hunting purposes. The Siniküla farm was founded during the establishment of home farms which started in 1985 . Two years later there were 4,700 birds on the farm. Changes in the board of the Ministry of Forestry and the incorporation of the Tartu Wood Factory with the wood processing industry Tarmeko brought along a rapid liquidation of the farm. In Estonia, pheasant farms have been founded also later, some being active even today. The study is mostly based on written reminiscences which have enabled to show that the marginal and exotic, yet attractive branch of bird breeding provides memories lasting over generations and still draws the attention of contemporary readers and the media. 